\title{
The HPV Vaccine: Are Dosing Recommendations Being Followed?
}

\author{
By
}

\section{Weiyi Tan}

\begin{abstract}
A Master's Paper submitted to the faculty of the University of North Carolina at Chapel Hill in partial fulfillment of the requirements for the degree of Master of Public Health in the Public Health Leadership Program.
\end{abstract}

Chapel Hill

2010

[signature]

Advisor: [printed name]

Date

[signature]

Second Reader: [printed name]

Date 


\section{Table of Contents}

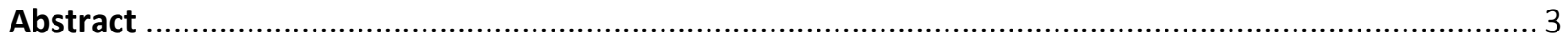

HPV vaccine initiation and completion rates and associated factors: a systematic review.

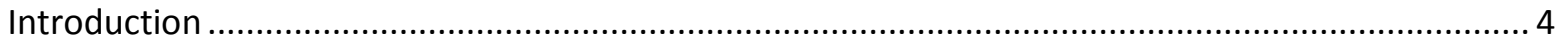

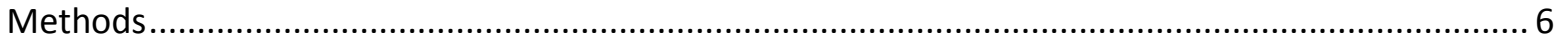

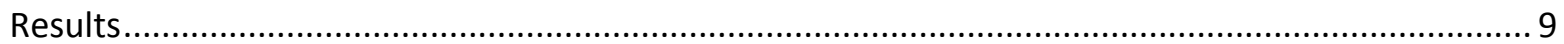

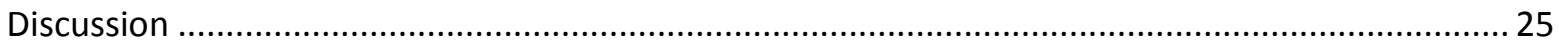

Secondary data analysis of the North Carolina Immunization Registry .............................................

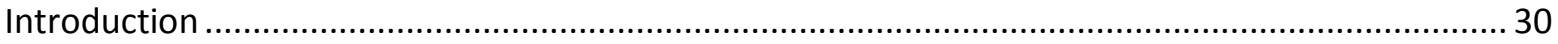

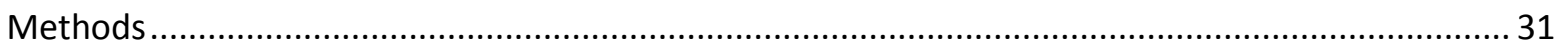

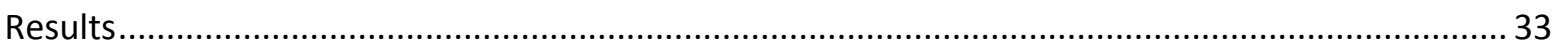

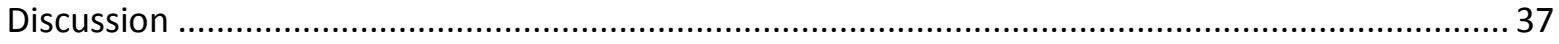

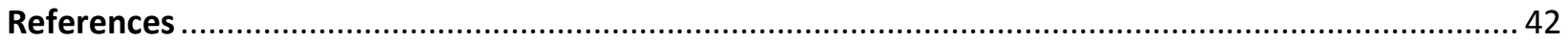

Figures and Tables

Systematic Review .....

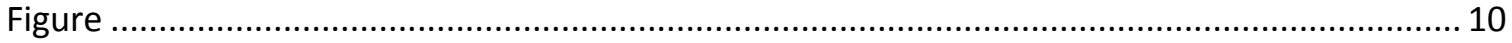

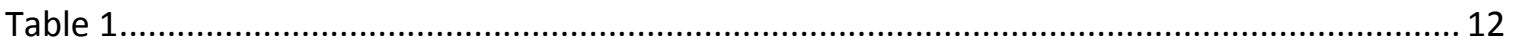

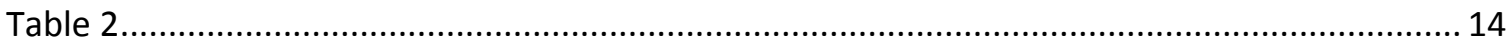

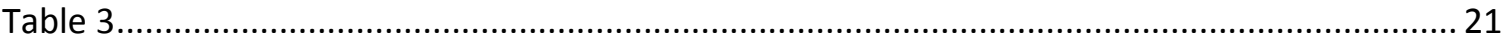

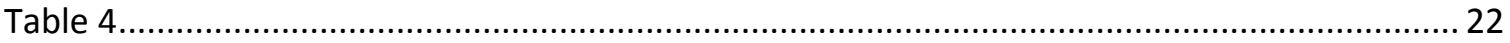

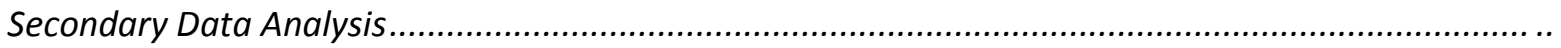

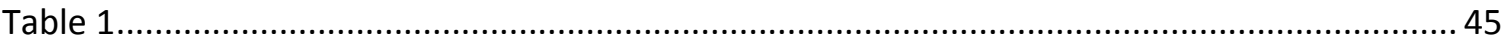

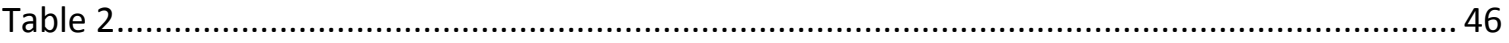

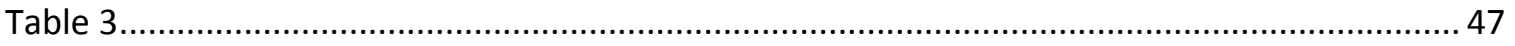

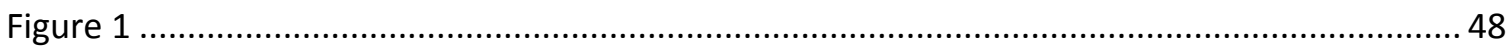

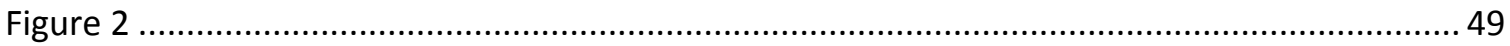




\begin{abstract}
Objective: This Master's paper aims to characterize the extent of HPV vaccination in the United States, and to summarize the current literature about HPV vaccination, series completion, and factors related to uptake and completion. It also aims to determine the percentage of HPV vaccine completion and on-time dosing, as well as identify factors associated with series completion and on-time dosing.

Design: We determined the rates of HPV vaccination and series completion through a systematic review. We also conducted a secondary data analysis of the North Carolina Immunization Registry (NCIR) to answer a focused clinical question about the rates of HPV vaccination completion and on-time dosing among a select population of females aged 9-26 years of age with at least one dose of the HPV vaccine.

Results: The literature review indicated that the rates of HPV vaccination vary widely depending on the type of patient population selected. Initiation rates varied between $5-77 \%$ and completion rates between $0.2 \%$ and $58.2 \%$. Correlates for uptake and series completion varied for each study, but most found associations between race, ethnicity, insurance status and the measured outcomes. Of the 138,823 females analyzed in the secondary data analysis, 55\% completed the vaccine series and $28 \%$ completed the series on-time. The percentage of those receiving the vaccine on-time has decreased each year from $43 \%$ in 2006 to $25 \%$ in 2009. African American race and public funding were significantly associated with lower rates of ontime dosing as well as series completion when compared to White race and private funding, respectively.

Conclusions: Although many studies in the literature were limited by flaws in study design or by small sample sizes, the review identified health disparities related to socioeconomic and racial disparities. The review also highlighted the fact that the HPV vaccination rate for both initiation and completion is relatively low when compared to other recommended vaccines. The secondary data analysis corroborated these findings. Among girls and young women who initiate the HPV vaccination series, overall completion rates are low, but given enough time (three years), most of those who begin the series will complete it. On-time dosing rates, however, are declining, and have been hovering at $25 \%$ for the past two years. The significance of delayed dosing with respect to vaccine immunogenicity and vaccine effectiveness are not well defined. Strategies to enhance both on-time receipt of HPV vaccine and series completion should be broadly encouraged.
\end{abstract}




\section{Introduction}

The human papillomavirus (HPV) infects an estimated 6.2 million people in the United States every year, and is the most common sexually transmitted infection. ${ }^{1}$ Persistent infection with high-risk HPV serotypes, particularly types 16 and 18, is the most important risk factor for developing cervical cancer ${ }^{1}$ while infection with HPV types 6 and 11 is responsible for most genital wart cases. ${ }^{1}$ The quadrivalent HPV vaccine (Gardasil@) is designed to prevent anogenital disease and cervical cancer associated with HPV types $6,11,16$, and $18 .^{2}$ Since HPV is such a common sexually transmitted infection, the HPV vaccine is most effective when administered prior to sexual debut. ${ }^{3}$ For this reason the Advisory Committee on Immunization Practices (ACIP) recommended to routinely vaccinate females 11-12 years of age in 2007. ${ }^{1}$ Catch-up vaccination of women not previously vaccinated extends up through 26 years of age. The American Academy of Pediatrics and the American Academy of Family Practitioners also espouse similar recommendations. ${ }^{4}$ In October of 2009, the ACIP updated its recommendations about HPV vaccination. ${ }^{5-6}$ The bivalent vaccine was also approved for use in females 9-26 years of age ${ }^{5}$ and the quadrivalent vaccine was approved for use in males 9-26 years of age in order to prevent anogenital warts. ${ }^{6}$ Nevertheless, the focus of this report is on the use of the vaccine in women, specifically the quadrivalent product, given the relatively recent introduction of the bivalent vaccine and use of the quadrivalent vaccine in males.

Despite the federal government's approval of the vaccine, its recommendation to vaccinate females from 9-26 years of age, ${ }^{1}$ and its addition of Gardasil ${ }^{\circledR}$ to the Vaccines for Children Program, ${ }^{7}$ the reported rates of HPV vaccination for young girls remains low. Nationally, only $37.2 \%$ of adolescent females (aged 13-17) had initiated the HPV vaccine series in 2008, and only $17.9 \%$ of females had received all 3 doses. ${ }^{8}$ The clinical trials demonstrating the effectiveness of 
the vaccine against cervical cancer and genital warts had high rates of compliance, ${ }^{9}$ and thus the effectiveness of the vaccine in girls who do not complete the series is unknown.

The quadrivalent vaccine is recommended to be administered as 3 separate doses with the $2^{\text {nd }}$ and $3^{\text {rd }}$ dose given at 2 and 6 months following the first dose, respectively. In clinical practice, it is likely that some females will receive their $2^{\text {nd }}$ and $3^{\text {rd }}$ vaccine doses at intervals outside the recommended dosing window. ${ }^{10-12}$ Currently, the standard of care is to finish the three-doses regardless of the schedule. ${ }^{1}$ There are limited data to assess how the late timing of the intervals between the $1^{\text {st }}$ and $2^{\text {nd }}$ or $2^{\text {nd }}$ and $3^{\text {rd }}$ dose of the vaccine will affect the humoral immune response, but studies are currently underway. ${ }^{13-16}$

To our knowledge, no systematic reviews about the uptake, completion, and adherence to dosing schedules of the HPV vaccine exist in the literature. Few studies have examined correlates for completion of the HPV vaccination series. ${ }^{17-19}$ However, we are aware of no study documenting factors associated with on-time dosing in addition to vaccine series completion. This report is a new systematic review of the current state of the literature on the subject. The review focuses on the completion rates of the HPV vaccine and on factors that are associated with series uptake or completion. The goal of this review is to highlight the extent to which the HPV vaccine is being completed when initiated, along with the factors associated with completion and uptake. This information will give insight into ways physicians, public health professionals, and policymakers can act in order to address the problems of low uptake and poor completion rates. Low uptake may reduce vaccine's impact on the population to prevent cervical cancer, while poor completion rates may reduce the effectiveness of the vaccine against cervical cancer and anogenital disease. 
In order to answer the question about actual uptake and completion of the HPV vaccine, we sought observational studies characterizing HPV vaccination rates (uptake or completion) and factors associated with vaccination in women between the ages of 9-26. Clinical trials were not chosen in this review due to the fact that trial settings have inflated adherence rates, and the goals of this review were to determine actual HPV vaccination rates in various real-world practice settings, as well as to determine socioeconomic and other demographic factors associated with these rates.

\section{Methods}

\section{Eligibility Criteria:}

Studies which included women living in the United States who were also between the ages of 9-26 (or any group within that range) were eligible for review. All observational study designs (cross-sectional, retrospective cohort, and prospective cohort) were eligible. Given the paucity of data, since the vaccine is relatively new, information from published abstracts without a corresponding published manuscript were also included. All controlled trials (randomized and non-randomized) that measured the effectiveness of an intervention program were excluded from the review in order to assess the completion rates of the HPV vaccination in a real-world clinical setting rather than in an experimental situation. Included studies had to have the primary outcome as the rate of vaccine uptake or vaccine completion. Studies examining socioeconomic and demographic factors associated with vaccine utilization were also included. Studies examining factors for vaccination acceptance (intention to receive the vaccine or openness to receiving the vaccine) were excluded from analysis due to the fact that acceptance and actual vaccine uptake are different outcomes that have different factors associated with them. Studies were limited to English speaking articles from 2006 until March 2010. This date range includes 
all studies since the FDA approval of the HPV quadrivalent vaccine, which was necessary for widespread dissemination and acceptance of the vaccine.

\section{Information Sources:}

We conducted literature searches using PubMed (2006-present) and Google Scholar (2006 present). Limits on both databases were set to English language articles published after 2006. The last search was run on March 8, 2010. In addition to database searching, studies were identified through the cross-checking of reference lists of the selected articles.

\section{Search Strategy:}

Search terms included the following MeSH terms in PubMed: Papillomavirus vaccines, vaccination statistics and numerical data, vaccination administration and dosage, vaccination trends, vaccination utilization, and immunization schedule. The following keywords were also used in both PubMed and Google Scholar: HPV vaccination rates, HPV vaccination uptake, delayed dosing vaccine, completion rates, timeliness, and completion.

The search strategy conducted using PubMed is shown below:

1. Papillomavirus Vaccines[Mesh] AND ("Vaccination/statistics and numerical data"[Mesh] OR "Vaccination/trends"[Mesh])

2. Papillomavirus Vaccines[Mesh] AND ("Vaccination/administration and dosage"[Mesh] OR "Vaccination/utilization"[Mesh])

3. Immunization Schedule[Mesh] AND "Papillomavirus Vaccines"[Mesh]

4. Papillomavirus Vaccines[Mesh] AND completion

5. HPV vaccination rates

6. HPV vaccination uptake

7. delayed dosing vaccine

8. ("Vaccination/administration and dosage"[Mesh] OR "Vaccination/statistics and numerical data"[Mesh] OR "Vaccination/trends"[Mesh] OR "Vaccination/utilization"[Mesh]) delayed

9. Immunization Schedule[Mesh] AND uptake

10. Immunization Schedule[Mesh] AND completion rates

11. Immunization Schedule[Mesh] AND timeliness 


\section{Study Selection:}

After the database searches, studies were screened based on relevant titles by the author (WT) in an unblinded manner. Eligible studies were then identified using abstracts to further narrow the selection to articles relevant to HPV vaccine uptake, series completion, and factors associated with both uptake and completion. Studies were excluded if they were not written in English, were clinical trials, or had a study population not based in the United States. The remaining articles were then fully reviewed by the author (WT).

Each stage of the study selection (screening, eligibility criteria, and full text review) was conducted by one author (WT) in an unblinded fashion. If the author had any concerns regarding the eligibility or relevancy of a study, he discussed the study with an expert methodologist (AV) and physician (EBW) who is an expert in the field of vaccines.

\section{Data Collection:}

The data from each study included in the full-text review were extracted using a standardized form based on a critical appraisal form that has been pilot tested and used in a graduate-level literature appraisal course at the UNC Gillings School of Global Public Health. I extracted the information from all the studies included in the full-text review.

The information extracted from each trial included: author, title, study year, study design/type, length of follow-up, source population, main results, study strengths, study weaknesses (biases), generalizability, conclusion, and overall study quality.

\section{Data Quality:}

When assessing risk of bias in individual studies, the author examined the risk of selection bias (patient selection, inclusion/exclusion criteria, loss to follow-up, dropouts), measurement bias (equal measurement methods, valid data collection methods, reliable tools), and 
confounding bias (statistical adjustments) in order to determine the quality and reliability of each study's results. Outcome level biases were not assessed given the paucity of data and heterogeneity between study populations and outcome measures.

The quality of each fully reviewed article was evaluated using an appraisal scheme based on USPSTF guidelines. Each article was graded based on its strength of study design, risk of bias, implementation, and generalizability of results. The article was then assigned a grade of poor, fair, or good. Since there are so few studies examining the completion rates of HPV vaccination and factors associated with uptake or series completion, poor quality studies were included in the review.

When reporting outcomes measures, the studies investigating vaccine uptake and series completion summarized rates in terms of percentages. The factors associated with uptake and completion were reported using either odds ratios or adjusted risk ratios.

The potential for publication bias or selective reporting is low as these are observational studies with results that would be informative regardless of the findings. Selective reporting of data might be a problem, but the methods and results were reviewed for each study to detect any discrepancy between stated design and reporting of the actual outcomes.

\section{Results}

\section{Study Selection:}

A total of 14 studies were identified for inclusion in the review (Figure). The initial literature search yielded 530 article citations. Based on the title alone, 390 articles were excluded as irrelevant. After reviewing the abstracts and excluding studies based on previously described criteria, such as experimental trials and studies about vaccine acceptability, 12 articles were identified for a full review. An additional two articles that fit eligibility criteria were identified 
by checking references of the 12 articles identified through the literature search. Of the 14 total studies included in the systematic review, one was an abstract that had no corresponding published full manuscript.

\section{Flow Diagram about Search Strategy}

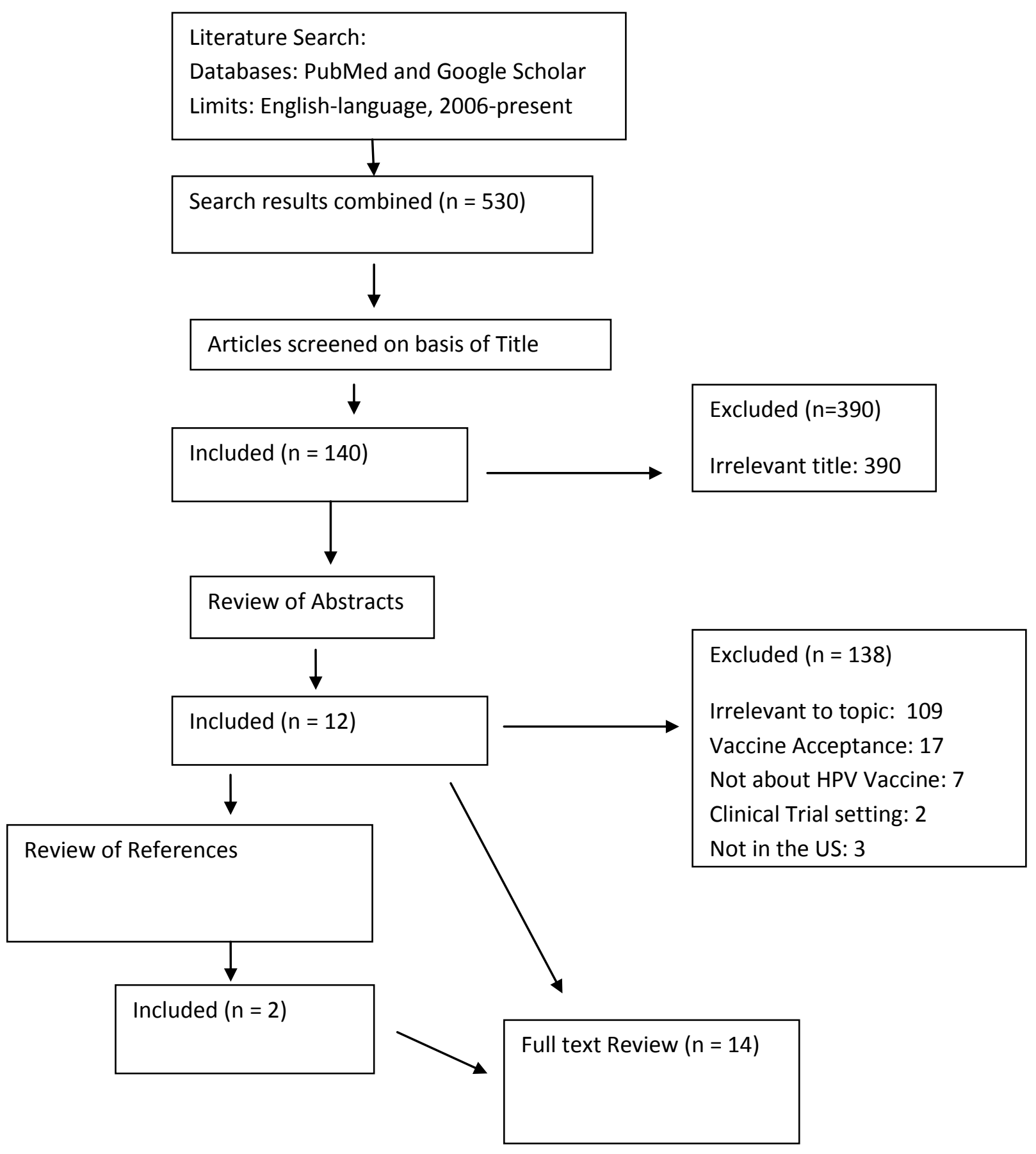




\section{Study Characteristics:}

The 14 studies were all observational reports published in English within the past four years. All the studies were based in the United States. Three of the studies ${ }^{17,20-21}$ were prospective cohort in design, three were retrospective cohort studies, ${ }^{18-19,22}$ and eight were cross-sectional studies. ${ }^{23-30}$ The prospective and retrospective cohort studies had follow-up periods ranging from 6 to 24 months with 5 out of 6 of these studies having follow-up periods lasting at least 12 months. ${ }^{17-20,22}$ The cross-sectional studies sampled their respective study populations between October of 2006 and November of 2008, and four studies sampled between May and October of 2007. ${ }^{23-25,27}$ The study populations for all 14 studies varied greatly; for example, some studies sampled from a large, managed care organization like Kaiser Permanente while another study used a small set of urban pediatric practices affiliated with one academic institution.

The cohort studies (both retrospective and prospective) enrolled females between the ages of 9 and 26 years, ${ }^{17,20}$ but some studies focused more on adolescents $(9-18 \text { years old })^{19,22}$ while others focused on young women (13-26 years old) ${ }^{21}$ These studies obtained their study population from a large managed care organization (Kaiser Permanente), ${ }^{17,20,22}$ an urban hospital-based teen health center, ${ }^{21}$ and university-based outpatient clinics. ${ }^{18-19}$ The crosssectional studies surveyed females between the ages of 11 and 26 years of age, ${ }^{24-27,29-30}$ as well as parents of females aged 9 to 18 years. ${ }^{23,28}$ Four studies used a nationally representative sample for their surveys, ${ }^{23-24,29-30}$ while four studies surveyed females from a specific area, such as two universities ${ }^{26}$ or five urban pediatric practices. ${ }^{27}$

Depending on the study in question, the outcomes addressed were either HPV vaccine initiation rates, HPV vaccine completion rates, or both. Three of the 14 articles concentrated on initiation rates of the HPV vaccine, ${ }^{20,24,27}$ two focused on completion rates, ${ }^{17-18}$ and six 
addressed both. ${ }^{19,21-22,25-26,30}$ The other three articles did not explicitly look at initiation or completion rates, but only at factors associated with vaccine uptake or series completion. ${ }^{23,28-29}$ Factors associated with either vaccine initiation or completion were discussed in all cohort studies $^{17-22}$ and in five of the eight cross-sectional studies. ${ }^{24,26,28-30}$ One cross-sectional study discussed factors associated with acceptance of a hypothetical 3-shot vaccine ${ }^{23}$ another discussed factors associated with intent to vaccinate,${ }^{25}$ while a third study did not discuss the subject. ${ }^{27}$ Please refer to Table 1 for a comprehensive review of the study characteristics.

Table 1. Study Characteristics

\begin{tabular}{|c|c|c|c|c|c|c|}
\hline Author & Title & Year & Design & Study Duration & $\begin{array}{c}\text { Source } \\
\text { Population }\end{array}$ & $\begin{array}{c}\text { Age } \\
\text { Range }\end{array}$ \\
\hline $\begin{array}{l}\text { Chao, et al } \\
\text { (1) }\end{array}$ & $\begin{array}{l}\text { Correlates for completion of } \\
\text { 3-dose regimen of HPV } \\
\text { vaccine in female members } \\
\text { of a managed care } \\
\text { organization }\end{array}$ & 2009 & $\begin{array}{l}\text { Prospective } \\
\text { Cohort }\end{array}$ & $\begin{array}{l}\text { Selected women } \\
\text { from } 10 / 06 \text { to } \\
3 / 07, \text { who } \\
\text { maintained } \\
\text { membership for at } \\
\text { least } 12 \text { months. } 1 \\
\text { Year post } \\
\text { Initiation, but } \\
\text { post-hoc analysis } \\
\text { up to } 2 \text { years post } \\
\text { initiation }\end{array}$ & $\begin{array}{l}\text { Kaiser } \\
\text { Permanente } \\
\text { Southern } \\
\text { California }\end{array}$ & 9 to 26 \\
\hline $\begin{array}{l}\text { Chao, et al } \\
\text { (2) }\end{array}$ & $\begin{array}{l}\text { Correlates for Human } \\
\text { Papillomavirus Vaccination } \\
\text { of Adolescent Girls and } \\
\text { Young Women in a } \\
\text { Managed Care Organization }\end{array}$ & 2010 & $\begin{array}{l}\text { Prospective } \\
\text { Cohort }\end{array}$ & 18 months & $\begin{array}{l}\text { Kaiser } \\
\text { Permanente } \\
\text { Southern } \\
\text { California }\end{array}$ & 9 to 26 \\
\hline $\begin{array}{c}\text { Chao, et al } \\
\text { (3) }\end{array}$ & $\begin{array}{c}\text { Papanicolaou Screening } \\
\text { Behavior in Mothers and } \\
\text { Human Papillomavirus } \\
\text { Vaccine Uptake in } \\
\text { Adolescent Girls }\end{array}$ & 2009 & $\begin{array}{l}\text { Retrospective } \\
\text { Cohort }\end{array}$ & $\begin{array}{l}12 \text { months for } \\
\text { initiation, } 18 \\
\text { months for } \\
\text { completion }\end{array}$ & $\begin{array}{l}\text { Kaiser } \\
\text { Permanente } \\
\text { Southern } \\
\text { California }\end{array}$ & 9 to 17 \\
\hline $\begin{array}{c}\text { Conroy, et } \\
\text { al }\end{array}$ & $\begin{array}{l}\text { Human Papillomavirus } \\
\text { Vaccine Uptake, Predictors } \\
\text { of Vaccination, and Self- } \\
\text { Reported Barriers to } \\
\text { Vaccination }\end{array}$ & 2009 & $\begin{array}{l}\text { Prospective } \\
\text { Cohort }\end{array}$ & 6 months & $\begin{array}{c}\text { Urban, } \\
\text { hospital-based } \\
\text { teen health } \\
\text { center } \\
\text { (location } \\
\text { unspecified) }\end{array}$ & 13 to 26 \\
\hline
\end{tabular}




\begin{tabular}{|c|c|c|c|c|c|c|}
\hline $\begin{array}{l}\text { Dempsey, } \\
\text { et al (1) }\end{array}$ & $\begin{array}{l}\text { Patient and Clinic Factors } \\
\text { associated with adolescent } \\
\text { human papillomavirus } \\
\text { vaccine utilization within a } \\
\text { university-based health } \\
\text { system }\end{array}$ & 2010 & $\begin{array}{c}\text { Retrospective } \\
\text { Cohort }\end{array}$ & 14 months & $\begin{array}{l}\text { University of } \\
\text { Michigan } \\
\text { Health System } \\
\text { outpatient } \\
\text { clinics for peds, } \\
\text { FM, and } \\
\text { ob/gyn }\end{array}$ & 9 to 18 \\
\hline $\begin{array}{c}\text { Dempsey, } \\
\text { et al (2) }\end{array}$ & $\begin{array}{l}\text { Parents' Views of } 3 \text { Shot- } \\
\text { Related Visits: Implications } \\
\text { for Use of Adolescent } \\
\text { Vaccines Like Human } \\
\text { Papillomavirus Vaccine }\end{array}$ & 2009 & $\begin{array}{l}\text { Cross- } \\
\text { Sectional } \\
\text { Survey }\end{array}$ & $\begin{array}{c}\text { Cross sectional, } \\
7 / 07-8 / 07\end{array}$ & $\begin{array}{l}\text { Random } \\
\text { sample of } 2906 \\
\text { adults from } \\
\text { Knowledge- } \\
\text { Panel (US } \\
\text { adults) }\end{array}$ & $\begin{array}{l}\text { Parents } \\
\text { of } 9 \text { to } 17 \\
\text { year olds }\end{array}$ \\
\hline Jain, et al & $\begin{array}{l}\text { Human papillomavirus (HPV) } \\
\text { awareness and vaccination } \\
\text { initiation among women in } \\
\text { the United States, National } \\
\text { Immunization Survey - Adult } \\
2007\end{array}$ & 2009 & $\begin{array}{l}\text { Cross- } \\
\text { Sectional } \\
\text { Survey }\end{array}$ & $\begin{array}{c}\text { Cross sectional, } \\
5 / 07-8 / 07\end{array}$ & $\begin{array}{l}\text { National } \\
\text { Immunization } \\
\text { Survey - Adult } \\
\text { (telephone } \\
\text { survey, } 7055 \\
\text { respondents) }\end{array}$ & 18 to 26 \\
\hline Kahn, et al & $\begin{array}{l}\text { Rates of Human } \\
\text { Papillomavirus Vaccination, } \\
\text { Attitudes about Vaccination, } \\
\text { and Human Papillomavirus } \\
\text { Prevalence in Young Women }\end{array}$ & 2008 & $\begin{array}{l}\text { Cross- } \\
\text { Sectional } \\
\text { Survey }\end{array}$ & $\begin{array}{c}\text { Cross-sectional, } \\
10 / 06 \text { to } 5 / 07\end{array}$ & $\begin{array}{l}\text { Hospital-based } \\
\text { teen health } \\
\text { center, ob/gyn } \\
\text { clinic, and std } \\
\text { clinic in } \\
\text { Cincinnati }\end{array}$ & 13 to 26 \\
\hline Licht, et al & $\begin{array}{l}\text { Is use of the HPV vaccine } \\
\text { among female college } \\
\text { students related to HPV } \\
\text { knowledge and risk } \\
\text { perception? }\end{array}$ & 2009 & $\begin{array}{l}\text { Cross- } \\
\text { Sectional } \\
\text { Survey }\end{array}$ & $\begin{array}{l}\text { Cross-sectional, } \\
\text { unknown date }\end{array}$ & $\begin{array}{c}\text { Two } \\
\text { universities } \\
\text { (location } \\
\text { unspecified) }\end{array}$ & 18 to 26 \\
\hline $\begin{array}{c}\text { Neubrand, } \\
\text { et al }\end{array}$ & $\begin{array}{c}\text { Factors Associated with } \\
\text { Completion of the Human } \\
\text { Papillomavirus Vaccine } \\
\text { Series }\end{array}$ & 2009 & $\begin{array}{c}\text { Retrospective } \\
\text { Cohort }\end{array}$ & $\begin{array}{l}17 \text { - } 23 \text { months } \\
\text { follow-up }\end{array}$ & $\begin{array}{l}\text { University- } \\
\text { based pediatric } \\
\text { clinic or } \\
\text { community } \\
\text { practice } \\
\text { (location } \\
\text { unspecified) }\end{array}$ & Under 21 \\
\hline Patel, et al. & $\begin{array}{l}\text { Are Our Adolescent Females } \\
\text { Becoming "One Less"? HPV } \\
\text { Vaccination Rates and } \\
\text { Barriers to Vaccination }\end{array}$ & 2009 & $\begin{array}{c}\text { Cross- } \\
\text { Sectional } \\
\text { Chart Review }\end{array}$ & $7 / 07$ - 10/07 & $\begin{array}{l}\text { Five Urban } \\
\text { Pediatric } \\
\text { Practices } \\
\text { affiliated with } \\
\text { an academic } \\
\text { institution in } \\
\text { New York City }\end{array}$ & 11 to 21 \\
\hline $\begin{array}{c}\text { Reiter, et } \\
\text { al }\end{array}$ & $\begin{array}{l}\text { How much will it hurt? HPV } \\
\text { vaccine side effects and } \\
\text { influence on completion of }\end{array}$ & 2009 & $\begin{array}{l}\text { Cross- } \\
\text { sectional } \\
\text { survey }\end{array}$ & $10 / 08-11 / 08$ & $\begin{array}{l}\text { Five North } \\
\text { Carolina } \\
\text { counties }\end{array}$ & $\begin{array}{l}\text { Parents } \\
\text { of } 10 \text { to } \\
18 \text { year }\end{array}$ \\
\hline
\end{tabular}




\begin{tabular}{|c|c|c|c|c|c|c|}
\hline & the three-dose regimen & & & & & olds \\
\hline $\begin{array}{c}\text { Rosenthal, } \\
\text { et al }\end{array}$ & $\begin{array}{l}\text { Predictors of HPV vaccine } \\
\text { uptake among women aged } \\
\text { 19-26: Importance of a } \\
\text { physician's recommendation }\end{array}$ & 2010 & $\begin{array}{c}\text { Case-control } \\
\text { survey }\end{array}$ & $\begin{array}{c}\text { 1/07 - 4/07, } 18 \\
\text { months follow-up }\end{array}$ & $\begin{array}{l}\text { Large US } \\
\text { managed care } \\
\text { plan affiliated } \\
\text { with i3 Innovus }\end{array}$ & 19 to 26 \\
\hline $\begin{array}{c}\text { Stokley, et } \\
\text { al }\end{array}$ & $\begin{array}{c}\text { National, State, and Local } \\
\text { Area Vaccination Coverage } \\
\text { Among Adolescents Aged } 13 \\
\text { - } 17 \text { Years -- United States, } \\
2008\end{array}$ & 2009 & $\begin{array}{l}\text { Cross- } \\
\text { Sectional } \\
\text { Survey }\end{array}$ & All of 2008 & $\begin{array}{l}\text { National } \\
\text { Immunization } \\
\text { Survey - Teen }\end{array}$ & 13 to 17 \\
\hline
\end{tabular}

\section{Outcome Results of Individual Studies:}

The results of each individual study are shown in the table below.

Table 2. Results of Individual Studies

\begin{tabular}{|c|c|c|c|}
\hline Author & $\begin{array}{c}\text { Initiation } \\
\text { Rates }\end{array}$ & Completion Rates & Factors Associated with Initiation or Completion \\
\hline $\begin{array}{c}\text { Chao, et al } \\
\text { (1) }\end{array}$ & $\mathrm{n} / \mathrm{a}$ & $\begin{array}{c}\text { Overall: } 42.8 \% \\
(12,663 \text { / } 29,598) \\
\text { 9-17 year olds: } \\
41.9 \%(10,347 \text { / } \\
24,676) \\
\text { 18-26 year olds: } \\
47.1 \%(2,316 / \\
4,922) \\
\\
\text { With } 2 \text { years of } \\
\text { follow-up, overall } \\
\text { completion rate } \\
\text { increased to } 50 \%\end{array}$ & $\begin{array}{c}\text { For } 9-17 \text { year olds: } \\
\text { Older age: } 17 \text { year olds versus } 11-12 \text { year olds } \\
\text { RR: } 0.87 \text { (0.82-0.93) } \\
\text { Black Race versus White: } \\
\text { RR: } 0.7 \text { (0.64-0.77) } \\
\text { Hispanics versus Whites: } \\
\text { RR: } 0.88 \text { (0.83-0.93) } \\
\text { Medi-cal coverage versus none: } \\
\text { RR: } 1.14 \text { (1.07-1.22) } \\
\text { Neighborhood education level (RR for a } 10 \% \text { in } \\
\text { percentage of adults with high school diploma in census } \\
\text { block) } \\
\text { RR: } 1.03 \text { (1.02-1.05) } \\
\text { For } 18-26 \text { year olds: } \\
\text { Same as younger group, but not statistically significant, } \\
\text { except for provider type. } \\
\text { Family medicine versus pediatrics: } \\
\text { RR: } 1.24 \text { (1.08-1.42) } \\
\text { Internal medicine versus pediatrics: } \\
\text { RR: } 1.26 \text { (1.06-1.50) }\end{array}$ \\
\hline
\end{tabular}




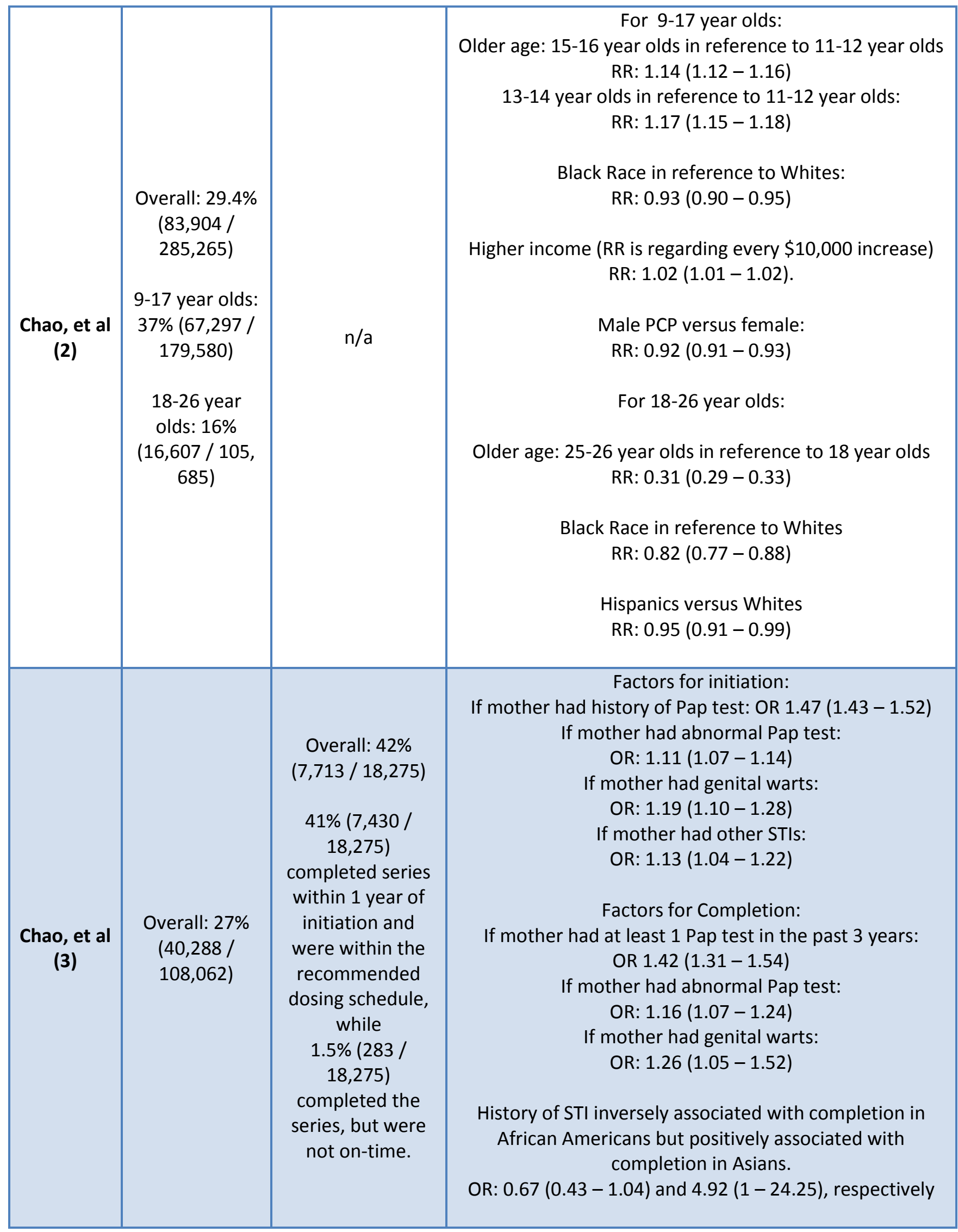




\begin{tabular}{|c|c|c|c|}
\hline $\begin{array}{c}\text { Conroy, et } \\
\text { al }\end{array}$ & $\begin{array}{c}\text { Overall: } 36 \% \\
\text { (68 / 189) }\end{array}$ & $\begin{array}{l}\text { Overall: } 13 \% \\
\text { (9 / 68) } \\
\text { 14.7\% (10 / 68) } \\
\text { initiated late } \\
\text { enough so they } \\
\text { weren't due for a } \\
\text { second dose by } \\
\text { the end of the } \\
\text { study, which } \\
\text { raises completion } \\
\text { rate to } 16 \% \text { ( } 9 \text { / } \\
58) \\
45 \% \text { ( } 26 / 58) \\
\text { were late for } 2^{\text {nd }} \\
\text { dose. }\end{array}$ & $\begin{array}{c}\text { Factors associated with Initiation: } \\
\text { Age, in years: } \\
\text { OR: } 0.64 \text { ( } 0.52-0.77) \text {, unadjusted } \\
\text { Insurance coverage for versus none: } \\
\text { OR: } 5.31(1.61-17.49) \\
\text { Normative beliefs (scale of } 1-5 \text { about how a patient } \\
\text { perceives importance of the vaccine): } \\
\text { OR: } 2.21(1.29-3.79)\end{array}$ \\
\hline $\begin{array}{l}\text { Dempsey, } \\
\text { et al }\end{array}$ & $\begin{array}{l}\text { Overall: } 28 \% \\
(2,855 / \\
10,082) \\
78 \%(2,038 / \\
2,625) \\
\text { received a } \\
\text { second dose }\end{array}$ & 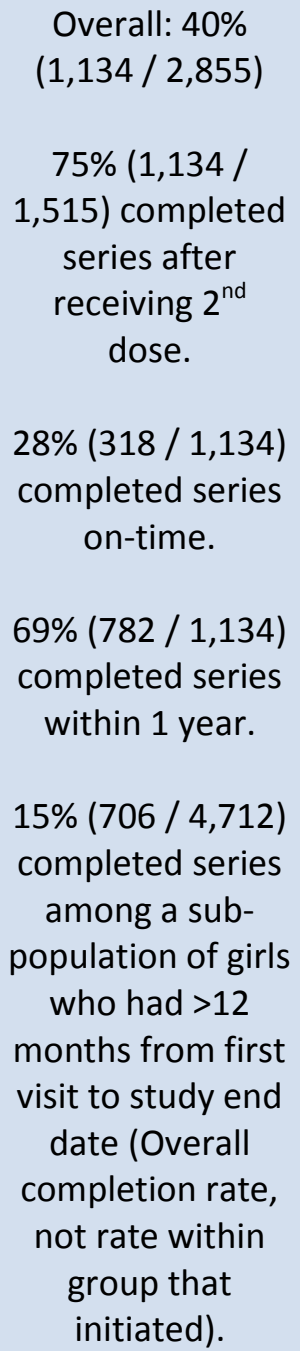 & $\begin{array}{c}\text { Factors associated with initiation: } \\
\text { Black race versus White race: } \\
\text { OR: } 1.06(0.91-1.24) \\
\text { Older age, } 16+\text { years old versus } 11-12 \text { year olds: } \\
\text { OR: } 1.92(1.66-2.23) \\
\text { Private Insurance versus Public Insurance: } \\
\text { OR: } 0.52 \text { (0.45 - 0.59) } \\
\text { Preventive visits versus problem-focused visits: } \\
\text { OR: } 5.18 \text { (4.64 - 5.79) } \\
\text { Factors associated with completion: } \\
\text { African-American race and public health insurance } \\
\text { associated with lower completion rates (absolute number } \\
\text { results not shown). }\end{array}$ \\
\hline Dempsey, & $\mathrm{n} / \mathrm{a}$ & $\mathrm{n} / \mathrm{a}$ & rs associated with NOT vaccinating (barriers): \\
\hline
\end{tabular}




\begin{tabular}{|c|c|c|c|}
\hline et al & & & $\begin{array}{c}\mathrm{N}=1025, \text { percentages don't add up to } 100 \text { because } \\
\text { parents could choose more than } 1 \text { barrier. } \\
\text { Unnecessary for healthy adolescents to be seen so } \\
\text { frequently: } 15 \%(12-17 \%) \\
\text { Adolescent would miss too much school: } 14 \%(11-17 \%) \\
\text { Problems getting off work: } 11 \%(8-14 \%) \\
\text { Too much time: } 10 \%(7-13 \%) \\
\text { Adolescent doesn't like shots: } 9 \%(6-11 \%) \\
\text { Against child receiving shots: } 7 \%(5-9 \%) \\
\text { No regular health care provider: } 2 \%(1-3 \%) \\
\text { Transportation problems: } 2 \%(1-4 \%)\end{array}$ \\
\hline Jain, et al & $\begin{array}{c}\text { Overall: } 10 \% \\
(17 / 168)\end{array}$ & $\mathrm{n} / \mathrm{a}$ & $\begin{array}{c}\text { Univariate Factors associated with initiation: } \\
\text { Not being married: } 11.8 \%(5.7-22.7 \%) \\
\quad>200 \% \text { FPL: } 22.8 \%(11.2-40.7 \%) \\
\text { Receiving Hep B vaccine: } 14.5 \%(7.2-27.2 \%) \\
\text { Having Insurance: } 12.5 \%(6.1-24.1 \%) \\
\text { Results of analysis of factors associated with HPV vaccine } \\
\text { initiation not presented due to lack of reliability caused } \\
\text { by small sample sizes. }\end{array}$ \\
\hline Kahn, et al & $\begin{array}{l}\text { Overall: } 5 \%(4 \\
\quad-7 \%)\end{array}$ & $\begin{array}{l}\text { Overall } 0.2 \% \text { ( } 0- \\
0.6 \%) \text { (measuring } \\
\text { out of all subjects, } \\
\text { not just those } \\
\text { who initiated) }\end{array}$ & $\begin{array}{l}\mathrm{n} / \mathrm{a} \text { (measured factors associated with vaccination intent } \\
\text { and beliefs of vaccination) }\end{array}$ \\
\hline Licht, et al & $\begin{array}{l}\text { Overall: } 43.6 \% \\
(177 / 406)\end{array}$ & $\begin{array}{l}\text { Overall: } 53 \%(93 / \\
177)\end{array}$ & $\begin{array}{l}\text { Factors associated with Initiation: } \\
\text { Age: Students 19-26 years old compared to } 18 \text { years old : } \\
\text { OR: } 0.27(0.17-0.41) \\
\text { African-American race compared to White race: } \\
\text { OR: } 0.26(0.08-0.81) \\
\text { Asians compared to Whites: } \\
\text { OR: } 0.42(0.18-0.99) \\
\text { HPV knowledge and vaccination status not related, } \\
\text { except for knowledge that genital warts are caused by } \\
\text { HPV } \\
\text { OR: } 1.85(1.20-2.93) \text {, adjusted }\end{array}$ \\
\hline $\begin{array}{l}\text { Neubrand, } \\
\text { et al }\end{array}$ & $\mathrm{n} / \mathrm{a}$ & $\begin{array}{l}\text { Overall: } 58.2 \% \\
\text { (205 / 352) } \\
\text { 12\% took more } \\
\text { than } 1 \text { year to } \\
\text { complete series. }\end{array}$ & $\begin{array}{l}\text { Factors associated with vaccine completion: } \\
\text { Bivariate analysis showed that Caucasians ( } 69.1 \% \\
\text { completed) were more likely to complete the series than } \\
\text { African Americans ( } 48.6 \% \text { completed) or Hispanics ( } 38.8 \% \\
\text { completed). } \\
\text { Private insurance ( } 65.6 \% \text { completed) also associated with } \\
\text { completion of the series when compared to those with }\end{array}$ \\
\hline
\end{tabular}




\begin{tabular}{|c|c|c|c|}
\hline & & & $\begin{array}{c}\text { Medicaid/SCHIP ( } 45.3 \% \text { completed). } \\
\text { Logistic Model: } \\
\text { Hispanics versus Caucasians: } \\
\text { OR: } 0.341(0.160-0.727) \\
\text { African-Americans and Caucasians did not differ } \\
\text { statically ( } p=0.081) \\
\text { If second visit was a nonstick visit versus a vaccine-only } \\
\text { visit: } \\
\text { OR: } 0.164 \text { ( } 0.078-0.343) \\
\text { No statistical difference between sick visit versus vaccine- } \\
\text { only visit ( } p=0.538)\end{array}$ \\
\hline $\begin{array}{l}\text { Patel, et } \\
\text { al. }\end{array}$ & $\begin{array}{l}\text { Overall: } 67 \% \\
11-12 \text { year } \\
\text { olds: } 55 \% \\
18-21 \text { year } \\
\text { olds: } 77 \%\end{array}$ & $\mathrm{n} / \mathrm{a}$ & $n / a$ \\
\hline $\begin{array}{c}\text { Reiter, et } \\
\text { al }\end{array}$ & $\mathrm{n} / \mathrm{a}$ & $\mathrm{n} / \mathrm{a}$ & $\begin{array}{c}\text { Factors associated with vaccine initiation: } \\
83 \%(154 / 186) \text { had pain from tetanus booster while } 62 \% \\
(116 / 186) \text { had pain from HPV vaccine at time of injection. } \\
\text { OR: } 6.43(2.88-16.90) \text {. } \\
70 \%(133 / 191) \text { had pain from tetanus booster while } 45 \% \\
(85 / 191) \text { had pain from HPV vaccine in the hours after } \\
\text { injection. OR: } 4.43(2.45-8.57) \text {. } \\
\text { Pain from vaccination did not influence timely uptake or } \\
\text { completion of vaccine. } 62 \% \text { (114/185) of parents of } \\
\text { daughters who completed series reported pain at time of } \\
\text { injection while } 68 \%(19 / 28) \text { of parents with daughters } \\
\text { who were late for their } 2^{\text {nd }} \text { or } 3^{\text {rd }} \text { dose reported pain. OR: } \\
0.76(0.33-1.77)\end{array}$ \\
\hline $\begin{array}{l}\text { Rosenthal, } \\
\text { et al }\end{array}$ & $\mathrm{n} / \mathrm{a}$ & $\mathrm{n} / \mathrm{a}$ & $\begin{array}{c}\text { Factors associated with vaccination: } \\
\text { Student status (yes versus no): } \\
\text { OR: } 2.79 \text { ( } 1.53-5.09) \\
\text { other): } \\
\text { OR: } 7.69(4.22-14.01) \\
\text { Physician Discussion (yes versus no): } \\
\text { OR: } 93.5 \text { ( } 39.1-223.6) \text {. } \\
\text { For people with discussion with a physician, each increase } \\
\text { of } 1 \text { point on the Likert scale was associated with a } 41 \% \\
\text { increase OR: } 1.41 \text { (1.06 - 1.88) in odds of vaccination. }\end{array}$ \\
\hline Stokley, et & Overall: $37.2 \%$ & Overall (whole & Factors associated with initiation: \\
\hline
\end{tabular}




\begin{tabular}{|c|c|c|c|}
\hline al & $\begin{array}{c}6,635 / \\
17,835) \text { in } \\
2008, \\
\text { compared with } \\
25.1 \% \text { ( } 740 \text { / } \\
2,947) \text { in } 2007 .\end{array}$ & $\begin{array}{c}\text { sample): } 17.9 \% \\
(3,193 / 17,835) \\
\text { Overall (among } \\
\text { those who } \\
\text { initiated): } 48.1 \% \\
(3,193 / 6,635)\end{array}$ & $\begin{array}{l}\text { Bivariate analysis: Hispanics had higher coverage than } \\
\text { Whites: } 44 \% \text { ( } 896 \text { / 2,017) versus } 35 \%(4,420 \text { / 12,628). } \\
\text { Adolescent females below poverty level had higher } \\
\text { vaccination initiation coverage for HPV vaccine than } \\
\text { those at or above poverty level: } 45.4 \%(993 / 2140) \text { versus } \\
35.8 \% \text { (5353/14951), but not } 3 \text { dose coverage (data not } \\
\text { shown). } \\
\text { Factors associated with completion: } \\
\text { Poorer females completed series at a rate of } 14.9 \% \text { ( } 319 \text { / } \\
2,140) \text { while richer females completed at a rate of } 18.6 \% \\
\text { (2,781 / 14,951). } \\
\text { Completion rates were } 19.5 \%(2,463 \text { / 12,628), 14.9\% } \\
(288 / 1,934) \text {, and } 14.7 \%(297 / 2,017) \text { for Whites, Blacks, } \\
\text { and Hispanics, respectively. }\end{array}$ \\
\hline
\end{tabular}

\section{Synthesis of Results:}

The study designs, participants, reported outcomes, and measured factors associated with the outcomes varied markedly for all of the 14 studies in this review, and therefore results are synthesized qualitatively rather than through a meta-analysis.

The results of the review show a wide range of initiation rates for the HPV vaccine varied between $5 \%$ and $77 \%$ (9 studies), with the majority of studies falling between $25 \%$ and $45 \%$ (6 studies). The completion rates of the vaccine varied between $0.2 \%$ and $58.2 \%$ ( 8 studies), with the majority of studies falling between $40 \%$ and $50 \%$ (4 studies). Three studies reported on-time dosing, but did not further describe factors associated with the finding. There was wide variability in the results, as demonstrated by the range of $1.5 \%$ to $72 \%$ for women receiving the vaccine in a delayed fashion.

In terms of factors associated with uptake, the studies varied in which correlates they decided to choose, the statistical methods in which they analyzed these factors, and also in the populations in which these correlates applied. Therefore, while it is difficult to combine the 
results, a few trends emerged. In the younger age group (under 18 years old), older age is associated with increased initiation. On the other hand, young women aged 18-26 years are more likely to initiate the vaccine if they are younger, which implies that vaccination initiation rates are highest in the late adolescent age group. Those who are too young (9-11 years old) or too old (24-26 years old) have not initiated HPV vaccination as much as the 14-18 year olds. A few studies also documented a racial/ethnic disparity where Whites had a higher rate of initiation than other races and ethnicities. Some studies, however, showed that Blacks were more likely to initiate the vaccine than Whites. One interesting study by Chao, et al. ${ }^{22}$ showed that mothers who received a recent pap smear or who had a history of warts, abnormal pap test, or other STI were more likely to have daughters who started the HPV vaccine. An association with insurance status is also unclear - one study reported that having insurance compared to no insurance is predictive of vaccination initiation, but another found that public insurance was better than private in terms of initiation rates.

In terms of factors associated with completion, the results were also difficult to synthesize given the same reasons highlighted above for the factors associated with vaccine initiation. Nevertheless, there are still a few trends of note. One is that people with private insurance more likely to complete the series than those with public insurance. Economically disadvantaged females also completed the series at a lower rate than those at or above the poverty level. The racial and ethnic disparities also exist, where Whites are more likely to complete the vaccine series than African Americans or Hispanics. The study by Chao, et al. investigating motherdaughter pairs also showed similar results to the initiation arm, except that African American mothers with a history of STI had daughters that were less likely to complete the series, but 
Asian mothers with a history of STI had daughters that were much more likely to complete the series. $^{22}$

\section{Study Quality:}

The cross-sectional studies have the greatest potential for confounding and temporal effects.

Many of the studies suffered from small sample sizes, large chunks of missing data, and poor generalizability. A summary of the major potential sources of bias in each study are shown in Table 3.

\section{Table 3. Risk of Bias within Studies}

\begin{tabular}{|c|c|}
\hline Author & Possible sources of Bias \\
\hline Chao, et al (1) & $\begin{array}{l}\text { Cannot capture all results outside of electronic system, had } 40-60 \% \text { missing data } \\
\text { for race/ethnicity (no mention of sample size in Logistic model) }\end{array}$ \\
\hline Chao, et al (2) & $\begin{array}{l}\text { A lot of missing data for race/ethnicity (50\%). No mention of sample size in } \\
\text { Logistic Model }\end{array}$ \\
\hline Chao, et al (3) & $\begin{array}{l}\text { A lot of exclusions limit generalizability, used census data to indicate SES. Also } \\
\text { used pap test history as a surrogate for mom's view on vaccination, which is not } \\
\text { an accurate representation of vaccine attitudes. No mention of sample size in } \\
\text { logistic model }\end{array}$ \\
\hline Conroy, et al & $\begin{array}{l}\text { Small sample, limited generalizability (hospital setting), short interval between } \\
\text { recruitment and study. }\end{array}$ \\
\hline Dempsey, et al (1) & $\begin{array}{l}\text { Small sample with respect to completion, limited generalizability (university } \\
\text { health system), no women over age } 18, \text { no subjects without insurance. }\end{array}$ \\
\hline Dempsey, et al (2) & $\begin{array}{l}\text { Hard to generalize, used a hypothetical vaccine scenario. Survey had fixed } \\
\text { responses which could bias answers. Response bias. }\end{array}$ \\
\hline Jain, et al & $\begin{array}{l}\text { Small sample (only } 168 \text { women), no females younger than } 18 \text { years old, a cross- } \\
\text { sectional design, subject to recall bias and non-response bias. Administered soon } \\
\text { after approval, early in the process. }\end{array}$ \\
\hline Kahn, et al & $\begin{array}{l}\text { Small sample, subject to selection bias and also did not have vaccine availability } \\
\text { in clinics. No absolute numbers reported, only percentages. }\end{array}$ \\
\hline Licht, et al & $\begin{array}{l}\text { Small sample, used convenience sample, so subject to selection bias. Weak study } \\
\text { design. No way to validate survey answers. Not generalizable, no age under } 18 \text {. }\end{array}$ \\
\hline Neubrand, et al & $\begin{array}{l}\text { Small sample, limited generalizability (only } 1 \text { academic center). Cannot capture } \\
\text { vaccinations outside clinic. Did not report sample used for logistic regression. }\end{array}$ \\
\hline Patel, et al. & $\begin{array}{l}\text { Poor information, not enough detail about the study. No absolute numbers } \\
\text { given, no definition of vaccination rate. }\end{array}$ \\
\hline Reiter, et al & Recall bias, parental opinion rather than vaccinee's. Small sample size. \\
\hline Rosenthal, et al & $\begin{array}{l}\text { Landline telephone survey, risk of sampling bias. Underestimate of vaccination } \\
\text { coverage due to incomplete records. Insufficient sample size for subgroup } \\
\text { analysis. }\end{array}$ \\
\hline
\end{tabular}


The table below summarizes each study's quality. Each study was evaluated based on an appraisal scheme outlined in the methods. Many studies had poor generalizability given a limited sample population and age restriction. The cohort studies were either fair or good quality, but most of the cohort studies were limited to one study site or location, ${ }^{19}$ and two of these studies were further limited by a small sample size. ${ }^{18,21}$ The exceptions, however, were three studies by Chao that included many patients captured from a data repository within a managed care organization in southern California. ${ }^{17,20,22}$ Nevertheless, the benefit of a large sample size was diminished by the fact the data set had large amounts of missing data and that the study population did not include subjects who lacked insurance or who were on public insurance.

The cross-sectional designs were much more varied in their quality; one was good quality, ${ }^{28}$ four were fair quality, ${ }^{23-24,26,30}$ and three were poor quality. ${ }^{25,27,29}$ Although poor quality studies were included in this review due to the paucity of literature on the subject, their results need to be cautiously interpreted given how fraught they are with flaws. For example, the study by Patel was only a published abstract with no corresponding full manuscript in publication, which gives the audience no idea about its quality or its methods. ${ }^{27}$ Another study assessed vaccination rates in clinics where the vaccine was unavailable for parts of the study period, which has the potential to greatly affect the outcome in question. ${ }^{25}$ The rest of the cross-sectional studies were mainly limited by the lack of response from survey participants, which might lead to a response bias.

Table 4. Evaluation of Each Study's Quality

\begin{tabular}{|c|c|c|c|c|}
\hline Author & Title & Generalizability & Conclusion & $\begin{array}{c}\text { Overall } \\
\text { Quality }\end{array}$ \\
\hline Chao, et al (1) & $\begin{array}{c}\text { Correlates for } \\
\text { completion of 3- }\end{array}$ & $\begin{array}{c}\text { Fairly good, but all } \\
\text { patients were within the }\end{array}$ & $\begin{array}{c}\text { HPV vaccination } \\
\text { completion rates are }\end{array}$ & Fair \\
\hline
\end{tabular}




\begin{tabular}{|c|c|c|c|c|}
\hline & $\begin{array}{l}\text { dose regimen of } \\
\text { HPV vaccine in } \\
\text { female members of } \\
\text { a managed care } \\
\text { organization }\end{array}$ & $\begin{array}{l}\text { insurance system. No } \\
\text { public insurance people }\end{array}$ & low & \\
\hline Chao, et al (2) & $\begin{array}{l}\text { Correlates for } \\
\text { Human } \\
\text { Papillomavirus } \\
\text { Vaccination of } \\
\text { Adolescent Girls and } \\
\text { Young Women in a } \\
\text { Managed Care } \\
\text { Organization }\end{array}$ & $\begin{array}{l}\text { Fairly good, but all } \\
\text { patients were within the } \\
\text { insurance system. No } \\
\text { public insurance people }\end{array}$ & $\begin{array}{c}\text { HPV vaccination } \\
\text { initiation is negatively } \\
\text { associated with black } \\
\text { race, low income, and } \\
\text { other factors. } \\
\text { Adolescents are more } \\
\text { likely to initiate than } \\
\text { young girls or young } \\
\text { women }\end{array}$ & Fair \\
\hline Chao, et al (3) & $\begin{array}{l}\text { Papanicolaou } \\
\text { Screening Behavior } \\
\text { in Mothers and } \\
\text { Human } \\
\text { Papillomavirus } \\
\text { Vaccine Uptake in } \\
\text { Adolescent Girls }\end{array}$ & $\begin{array}{l}\text { Good - wide patient } \\
\text { population, even with } \\
\text { many exclusions. }\end{array}$ & $\begin{array}{l}\text { Daughters who } \\
\text { received HPV vaccine } \\
\text { were } 50 \% \text { more likely } \\
\text { to have a mom with a } \\
\text { pap test in the past } 3 \\
\text { years. Vaccine } \\
\text { completion was only } \\
41 \% \text { within } 1 \text { year, but } \\
\text { most were on time. }\end{array}$ & Fair \\
\hline Conroy, et al & $\begin{array}{c}\text { Human } \\
\text { Papillomavirus } \\
\text { Vaccine Uptake, } \\
\text { Predictors of } \\
\text { Vaccination, and } \\
\text { Self-Reported } \\
\text { Barriers to } \\
\text { Vaccination }\end{array}$ & $\begin{array}{l}\text { Poor - small sample, } \\
\text { from an urban, hospital- } \\
\text { based adolescent } \\
\text { primary care clinic. }\end{array}$ & $\begin{array}{l}\text { HPV vaccination rates } \\
\text { were low }(36 \%) \text {, and } \\
\text { completion was even } \\
\text { lower }(13 \%) \text {. Factors } \\
\text { associated with } \\
\text { vaccination included } \\
\text { insurance and } \\
\text { normative beliefs. }\end{array}$ & Fair \\
\hline Dempsey, et al (1) & $\begin{array}{c}\text { Patient and Clinic } \\
\text { Factors associated } \\
\text { with adolescent } \\
\text { human } \\
\text { papillomavirus } \\
\text { vaccine utilization } \\
\text { within a university- } \\
\text { based health system }\end{array}$ & $\begin{array}{l}\text { Poor - university setting, } \\
\text { and no women over age } \\
18 .\end{array}$ & $\begin{array}{c}\text { HPV vaccination } \\
\text { initiation is associated } \\
\text { with African American } \\
\text { Race and public } \\
\text { insurance. Completion } \\
\text { is associated with } \\
\text { White race and } \\
\text { Private insurance. } \\
\text { Completion rates are } \\
\text { low. }\end{array}$ & Good \\
\hline Dempsey, et al (2) & $\begin{array}{l}\text { Parents' Views of } 3 \\
\text { Shot-Related Visits: } \\
\text { Implications for Use } \\
\text { of Adolescent } \\
\text { Vaccines Like } \\
\text { Human }\end{array}$ & Fair - response bias & $\begin{array}{l}\text { Among national } \\
\text { sample of parents of } \\
\text { adolescents, high } \\
\text { willingness to } \\
\text { participate in 3-dose } \\
\text { vaccination visits, but }\end{array}$ & Fair \\
\hline
\end{tabular}




\begin{tabular}{|c|c|c|c|c|}
\hline & $\begin{array}{l}\text { Papillomavirus } \\
\text { Vaccine }\end{array}$ & & $\begin{array}{l}\text { many barriers } \\
\text { included lack of } \\
\text { perceived need for } \\
\text { frequent visits. }\end{array}$ & \\
\hline Jain, et al & $\begin{array}{c}\text { Human } \\
\text { papillomavirus } \\
\text { (HPV) awareness } \\
\text { and vaccination } \\
\text { initiation among } \\
\text { women in the } \\
\text { United States, } \\
\text { National } \\
\text { Immunization } \\
\text { Survey - Adult } 2007\end{array}$ & $\begin{array}{l}\text { Poor - not the right age } \\
\text { group }\end{array}$ & $\begin{array}{l}\text { Vaccination initiation } \\
\text { was } 10 \% \text { among } \\
\text { women } 18-26 \text { years } \\
\text { old, and initiation is } \\
\text { associated with not } \\
\text { being married, having } \\
\text { insurance. }\end{array}$ & Fair \\
\hline Kahn, et al & $\begin{array}{c}\text { Rates of Human } \\
\text { Papillomavirus } \\
\text { Vaccination, } \\
\text { Attitudes about } \\
\text { Vaccination, and } \\
\text { Human } \\
\text { Papillomavirus } \\
\text { Prevalence in Young } \\
\text { Women }\end{array}$ & $\begin{array}{l}\text { Poor - no vaccine } \\
\text { availability }\end{array}$ & $\begin{array}{c}\text { Vaccine initiation was } \\
\text { only } 5 \% \text {. Completion } \\
\text { was only } 0.2 \% \text {. }\end{array}$ & Poor \\
\hline Licht, et al & $\begin{array}{l}\text { Is use of the HPV } \\
\text { vaccine among } \\
\text { female college } \\
\text { students related to } \\
\text { HPV knowledge and } \\
\text { risk perception? }\end{array}$ & $\begin{array}{l}\text { Fair - college students } \\
\text { seem to be quite varied. }\end{array}$ & $\begin{array}{c}\text { Vaccine initiation was } \\
43.6 \% \text {. Completion } \\
\text { was } 53 \% \text { among those } \\
\text { who did start. } \\
\text { Younger age and } \\
\text { White race associated } \\
\text { with vaccination. }\end{array}$ & Fair \\
\hline Neubrand, et al & $\begin{array}{l}\text { Factors Associated } \\
\text { with Completion of } \\
\text { the Human } \\
\text { Papillomavirus } \\
\text { Vaccine Series }\end{array}$ & $\begin{array}{c}\text { Fair - small sample, only } \\
1 \text { academic center } \\
\text { sampled. }\end{array}$ & $\begin{array}{l}\text { Completion rate is } \\
58.2 \% \text {. Race (Hispanic) } \\
\text { associated with less } \\
\text { completion in } \\
\text { multivariate logistic } \\
\text { model. }\end{array}$ & Fair \\
\hline Patel, et al. & $\begin{array}{l}\text { Are Our Adolescent } \\
\text { Females Becoming } \\
\text { "One Less"? HPV } \\
\text { Vaccination Rates } \\
\text { and Barriers to } \\
\text { Vaccination }\end{array}$ & $\begin{array}{l}\text { Poor - no idea about } \\
\text { quality of the study }\end{array}$ & $\begin{array}{l}\text { Vaccination for HPV is } \\
\text { lower than tetanus } \\
\text { vaccination in an } \\
\text { urban practice setting. }\end{array}$ & Poor \\
\hline Reiter, et al & $\begin{array}{l}\text { How much will it } \\
\text { hurt? HPV vaccine } \\
\text { side effects and } \\
\text { influence on } \\
\text { completion of the }\end{array}$ & $\begin{array}{l}\text { Fair - patients were } \\
\text { oversampled for 10-18 } \\
\text { year old daughters, } \\
\text { African American race, } \\
\text { and rural. }\end{array}$ & $\begin{array}{l}\text { Pain is not related to } \\
\text { vaccine uptake. }\end{array}$ & Good \\
\hline
\end{tabular}




\begin{tabular}{|c|c|c|c|c|}
\hline & three-dose regimen & & & \\
\hline Rosenthal, et al & $\begin{array}{l}\text { Predictors of HPV } \\
\text { vaccine uptake } \\
\text { among women aged } \\
\text { 19-26: Importance } \\
\text { of a physician's } \\
\text { recommendation }\end{array}$ & $\begin{array}{l}\text { Poor - poor response } \\
\text { rate, sampling bias }\end{array}$ & $\begin{array}{c}\text { Physician } \\
\text { recommendation and } \\
\text { discussion is vital for } \\
\text { vaccine initiation } \\
\text { among } 19-26 \text { year } \\
\text { olds. }\end{array}$ & Poor \\
\hline Stokley, et al & $\begin{array}{l}\text { National, State, and } \\
\text { Local Area } \\
\text { Vaccination } \\
\text { Coverage Among } \\
\text { Adolescents Aged } \\
13 \text { - } 17 \text { Years -- } \\
\text { United States, } 2008\end{array}$ & $\begin{array}{l}\text { Fair - large national } \\
\text { sample, but because of } \\
\text { telephone survey and } \\
\text { loss of respondents } \\
\text { (only } 58.7 \% \text { response } \\
\text { rate), it's hard to } \\
\text { generalize }\end{array}$ & $\begin{array}{c}\text { 37.2\% initiation rate, } \\
\text { 17.9\% completion } \\
\text { rate. }\end{array}$ & Fair \\
\hline
\end{tabular}

\section{Discussion}

\section{Summary of Evidence:}

Overall, the evidence is too heterogeneous for the data to be combined in a meta-analysis.

Nevertheless, the studies themselves point to a HPV vaccine initiation rate between $25-45 \%$, depending on the specific patient population (11-12 year olds or 18-26 year olds for example). This number is likely to increase over time as the vaccine becomes more established within the medical system and becomes more accepted as a safe and efficacious option against cervical cancer. The vaccine completion rates also varied greatly, but most studies indicated a completion rate (sampling only from a group that initiated) between $40-50 \%$. The overall completion rate, which refers to the number of females who completed the vaccine series out of the entire group of eligible subjects (not just the ones who initiated), ranged between $15-18 \%$ in two studies. ${ }^{19,30}$

When discussing correlates for vaccine initiation or series completion, many studies employed varied statistical methods to find significant predictors, such as a log-log binomial regression model, logistic regression, or simple bivariate analyses. Given the different methods, the outputs were different as well; some studies used risk ratios, others used odds ratios, and some used percentages. While it is difficult to compare the numbers, the conclusions were 
similar across all studies. Vaccine initiation and completion are associated with covariates like age, race, ethnicity, insurance type and status, socioeconomic status, normative beliefs about the vaccine, a mother's pap smear history, and discussion with a physician. Some studies found that economically disadvantaged females or minorities like Hispanics or African Americans had paradoxically higher rates of vaccine initiation, but that may be due to the fact that economically disadvantaged patients have access to the Vaccines for Children program and do not have to face the financial barrier of paying for the vaccine that some privately insured patients face. The majority of African-Americans and Hispanics in some of these studies were also below the poverty level - which might indicate that the higher vaccination initiation rates might be due to socioeconomic factors rather than racial factors. ${ }^{19,} 30$ When looking at completion rates, however, private insurance and White race become predictors for completion, which then indicates that there might be some differences between getting a patient to initiate the vaccine and having them return for the $2^{\text {nd }}$ and $3^{\text {rd }}$ visit to complete the series.

It is quite difficult for a clinician to apply the literature known about HPV vaccine to his or her patient population since each study has a specific target patient population (limited by age range, practice location, and insurance status), and has limitations that impair its generalizability (poor study design, lack of adequate follow-up, or even lack of vaccine availability during the study period). Furthermore, with the exception of the MMWR report utilizing 2008 data, most of the studies cite data collected either in 2006 or 2007. Hopefully this report has synthesized the data available so that a clinician may apply the current knowledge about vaccination rates to his or her own patient population.

Thus, a study with a larger, representative sample of patients with enough follow-up periods to adequately capture enough data for completion rates and factors associated with those is 
needed. While three of the studies also looked at on-time dosing rates, they were not explicitly discussed and had no correlates for on-time dosing either.

\section{Limitations:}

At the outcome level, the main limitation of trying to compare each of the studies is that the patient population and follow-up periods are not the same across studies. Various studies had shorter follow-up times which would decrease completion rates, and furthermore, the different patient populations studied might also lead to systematic differences in vaccination rates and correlates for uptake or completion. This makes it hard to make generalizable statements when pooling the outcomes. Furthermore, some studies measured completion rates of the HPV vaccine relative to the entire study population while other studies measured completion rates within a cohort of patients that initiated the vaccine. Therefore, it is difficult to compare completion percentages without knowing the absolute numbers, and some studies did not provide the number of patients that initiated the vaccine.

At the study level, many of the studies had limitations due to small sample size, missing data, or weak study design. A lot of the studies were cross-sectional surveys, which subjects the results to recall bias and non-response bias. Furthermore, although a cross-sectional survey design is good for detecting prevalence of a condition (such as vaccine uptake), it cannot appropriately address vaccination completion rates, given that completion of the series is timedependent; some females who would complete the series might not be captured with a survey at that moment in time. The cohort studies (retrospective or prospective) were limited by missing data (2 studies), a small sample size (2 studies), and limited generalizability due to a selective patient population (4 studies). Many studies also used logistic regression models to find significant predictors of vaccine initiation or completion. Very few of these studies, however, 
reported about the sample sizes used in the models, and what impact missing data had on the study results.

\section{Conclusions:}

The quadrivalent HPV vaccine has only been available for a short period of time (less than 4 years). There have been no systematic reviews attempting to document the national rate of vaccine initiation or completion. When discussing HPV vaccine initiation and completion rates, one of the most widely quoted studies is the CDC report about vaccination coverage among adolescents aged 13-17 years in the US. ${ }^{30}$ This phenomenon may be due to its governmental affiliation, national sample, and recent publication, but the study is limited by its methods (telephone survey) and its low response rate (58.7\%). Furthermore, they did not have enough data to make conclusions about 2007 completion rates. Nevertheless, initiation rates around 37\% and completion rates of $17.9 \%$ (but $41.8 \%$ of those that initiated) in 2008 have been cited by many studies as truly representative of the national rate.

Thus an implication for future research would be to update the literature using more current data about the HPV vaccination rates. A study with a longer follow-up period could also increase the robustness of the results and the use of a more inclusive study population (i.e. using 9-26 year olds instead of 13-17 year olds) would yield more generalizable results as well. Lastly, a study investigating the rates of on-time dosing would be helpful given the paucity of data on the

subject. Given the fact that there is no evidence regarding the efficacy of the HPV vaccine with a delayed dosing schedule or an incomplete dosing regimen, knowing the prevalence of both problems might be informative for development of interventions to boost vaccination rates if future studies do show a decrease in efficacy given poor adherence to the recommended dosing schedule or incomplete vaccination. 


\section{Funding:}

This systematic review was not funded by any source. The author has no conflicts of interest to disclose. 


\section{Introduction:}

The human papillomavirus (HPV) infects an estimated 6.2 million people in the United States every year, making it the most commonly sexually transmitted infection (STI). ${ }^{1}$ Persistent infection with high-risk HPV serotypes, including types 16 and 18, is the most important risk factor for developing cervical cancer ${ }^{1}$ while infection with HPV types 6 and 11 is responsible for most anogenital wart cases. ${ }^{1}$ The quadrivalent HPV vaccine (HPV4, Gardasil) is designed to prevent cervical cancer and anogenital warts by preventing infection with HPV types 6, 11, 16, and $18 .^{2}$ Since HPV is a widespread STI, the HPV vaccine is most effective when administered prior to sexual debut. ${ }^{3}$ Therefore, the Advisory Committee on Immunization Practices (ACIP) recommends routine vaccination of girls starting at 11-12 years of age with catch-up vaccination of vaccine naïve young women suggested up through 26 years of age. ${ }^{1}$ The HPV4 vaccine is administered as a 3 dose series with the $2^{\text {nd }}$ and $3^{\text {rd }}$ dose given at 2 and 6 months following the first dose, respectively.

Despite the ACIP's recommendation and the government's support in making HPV4 vaccine series available through the Vaccines For Children (VFC) Program, ${ }^{4}$ the reported rates of HPV vaccination remain low. Nationally, only 37.2\% of adolescent females (aged 13-17) had initiated the HPV vaccine series in 2008, and only $17.9 \%$ of the adolescent females had received all 3 doses. ${ }^{8}$ Furthermore, adherence to the recommended dosing intervals is likely to be poor among adolescents. $^{10-12}$

A few studies have examined correlates for completion of the HPV vaccination series. ${ }^{17-19}$ However, we are not aware of any studies documenting factors associated with on-time dosing in addition to vaccine series completion. Therefore, the goal of this study was to measure the rates of HPV vaccine series completion and on-time dosing based on the recommended schedule 
among those who initiate the series, along with factors associated with series completion and ontime dosing. This information may be helpful in developing strategies to increase on-time completion of HPV vaccination among adolescent girls.

\section{Methods:}

Study Design

This retrospective cohort study was a secondary data analysis of computerized immunization records in the state of North Carolina. The study protocol was submitted to the Duke University Health System Institutional Review Board (IRB) and exempted from full review.

\section{Data Source}

The North Carolina Immunization Registry (NCIR) is a statewide database containing information on immunizations delivered in all the health departments and more than 600 private practices throughout the state. As of $2009,72 \%$ of public providers and $61 \%$ of private providers used the registry to record immunizations. A public provider is defined as a public health department, a community/migrant health/rural health clinic, Indian health service clinic, or any public clinic that provides immunizations, such as a publically funded non-profit neighborhood clinic. A private provider is defined as a private health plan, group of doctors, or clinic that is not a federally qualified health center (FQHC). For each individual included in the dataset there are fields for the person's county of residence, race, ethnicity, and each vaccination date. For every individual vaccination date the recipient's age, clinic type, and funding source for the vaccine could also be entered.

\section{Study Population}

Our study sample consisted of all females whose immunization information was included in the NCIR and who received at least one dose of the HPV vaccine series of which the first dose 
was administered between 9 and 26 years of age. Entries were excluded if the date of the first dose entered was before 6/8/2006 (the day the FDA approved the HPV4 vaccine) or after 2/17/2009 (to allow time for all those in the study to potentially complete the series on-time before the date of data censoring). For these reasons, of the 172,948 girls and young women in the data set, 34,118 were excluded (273 were less than 9 years of age, 185 were greater than 26 years of age, 286 entries had a first dose before 6/8/2006, and 33,374 entries had a first dose after 2/17/2009). Seven entries with obviously discordant dates, such as duplications or vaccinations only days apart, were also excluded from analysis. Our final sample consisted of 138,823 girls and young women.

\section{Variables}

The main outcomes were completion of the HPV vaccine series and on-time completion of the vaccine series. Completion of the series was defined as documentation of at least 3 separate HPV vaccine doses. On-time completion was assessed by the intervals between the three doses. An on-time dose was defined as $2 \pm 1$ months (28-84 days) between the first two doses and $6 \pm 2$ months (112-224 days) between the first and third doses as outlined by the HPV4 package insert. ${ }^{13}$ This dosing window was used since studies by Merck have shown no reduction in immunogenicity with the aforementioned schedule flexibility. ${ }^{13}$

The exposure variables examined were: race, ethnicity, age, county of residence, the clinic type, and funding type. Race was categorized as American Indian/Alaska Native, Asian, Black/African-American, Native Hawaiian/Pacific Islander, Other, or White. Ethnicity was divided into Hispanic or non-Hispanic. Clinic type (Family, local health department, hospital, internal medicine, juvenile corrections, K-12 school, university/college, pediatrician, or other), source of funding (public or private), and age (in months) of the recipient were listed for each 
vaccine dose. Each variable was not self-reported, but rather manually entered for each entry by the provider using the registry.

\section{Data Analysis}

We used means or proportions to describe the characteristics of the girls and young women in the sample. We examined factors associated with series completion as well as on-time dosing using unadjusted bivariate analyses and tested for significance using Pearson's chi-squared test. We used logistic regression to examine the independent effects of the exposure variables on series completion and on-time dosing. The subjects were categorized into three age groups, 9-12 years of age (young girls), 13-17 years of age (adolescents), and 18-26 years of age (young women), in order to compare the differences among age groups with regards to vaccination completion and on-time dosing. Counties were classified as metropolitan statistical areas based on US census data. ${ }^{31}$ For the logistic regression analysis, age, funding source and clinic type were based on the first dose of the vaccine. We used listwise deletion to handle missing data. This method of logistic regression ignores all entries with missing data and only uses entries with a complete set of variables in the analysis, which yields a complete-case analysis. To examine the effect of missing data, we created a regression model with dummy variables for all unknowns and compared it to the complete-case analysis. All p-values were considered significant at $\leq 0.05$ and $95 \%$ confidence intervals were reported when appropriate. Stata Version 11.0 (Statacorp, College Station, TX) was used for all analyses.

\section{Results}

\section{Characteristics of the Study Population}

The girls and young women in the cohort were mainly White (63\%) and non-Hispanic (91\%) (Table 1). They lived mostly in metropolitan statistical areas (70\%), and about half had private 
insurance. The median age was 14.8 years, 15.1 years, and 15.3 years at doses 1,2 , and 3 respectively. The average length of follow-up was 19 months, with a range of 8 months to 40 months.

\section{Completion Rates and On-Time Dosing}

Of the 138,823 girls and young women in the study population, $23 \%(n=31,771)$ received a single dose of the quadrivalent HPV vaccine; $22 \%(\mathrm{n}=30,561)$ received only two doses; $55 \%(\mathrm{n}$ $=76,491)$ completed the HPV vaccine series. Approximately $28 \%$ of the entire group $(\mathrm{n}=$ 39,123), completed the HPV vaccine series on-time (Figure 1). For those who received a dose that was not on-time, the median interval in relation to the first dose was 5.7 months for the second dose and 10.8 months for the third dose. Most of the girls and young women (82\%) who completed the series did so within 12 months, and nearly all (98\%) had completed the series by 24 months. Over $83 \%$ of those $(3,354 / 4,013)$ who initiated the vaccine series in 2006 completed it by the final study date, compared to $32 \%(1,585 / 4,985)$ of those who initiated the vaccine in 2009. The percentage of girls and young women who have completed the series on-time out of those who initiated the series has decreased each year, from 43.2\% $(1,732 / 4,013)$ in 2006 to $25.2 \%(1,258 / 4,985)$ in 2009 (Figure 2). Among those who received the second dose on time, $72.8 \%$ received the third dose on time, whereas only $19.6 \%$ of females received the third dose on time if they were late in receiving the second dose ( $\mathrm{p}$-value $<0.001)$. Factors Associated with Vaccine Completion and On Time Vaccine Dosing

Vaccine series completion and on-time series completion varied significantly with race ( $\mathrm{p}<0.001$ for both) with Whites more likely than Blacks to complete the series (59\% vs. $43 \%)$ as well as complete the series on-time (55\% vs. $43 \%)$. Non-Hispanics were also more likely than 
Hispanics to both complete the series (54\% vs. $46 \%$, p<0.001) and do so on-time (51\% vs. $47 \%$, $\mathrm{p}<0.001)$.

Both those 9-12 years of age and 13-17 years of age had similar completion rates $(57 \%)$ that were higher than those 18-26 years of age (42\%). Nevertheless, when comparing on-time dosing rates, of those 18-26 years of age who completed the series $55 \%$ did so on-time, compared with approximately $50 \%$ of those $9-12$ years of age and 51\% of those $13-17$ years of age. Compared to those whose vaccine was publically funded, the girls and young women whose vaccine was funded by private insurance were more likely to complete the series $(61 \%$ vs. $46 \%, \mathrm{p}<0.001$ and do so on-time (54\% vs., $47 \%, \mathrm{p}<0.001)$

Completion and on-time dosing rates differed by the type of health care clinic from which the girls and young women received immunizations. Those vaccinated at pediatric clinics had the highest completion rates at $61 \%$, followed by those vaccinated at family medicine practices at $53 \%$ and those vaccinated at local health departments at $39 \%$. For on-time dosing, girls and young women vaccinated at family medicine practices had the highest rate at $56 \%$, while those vaccinated at pediatric clinics or at local health departments had on-time dosing rates at $50 \%$.

Of those who completed the series $(n=76,491)$, the vast majority $(96.1 \%)$ stayed with the same clinic, and $52 \%$ of them completed the series on-time. Only $28 \%$ of those who switched clinic type, however, completed the series on-time. Additionally, 85\% (47,802 / 56,389) of females who completed the series stayed with the same funding source, and $52 \%$ of them completed the series on-time. Among those who switched funding sources, $47 \%$ completed the series on time. 
Independent Associations with Vaccine Completion

Compared to Whites, African-Americans were less likely to complete the series (OR 0.55; 95\% CI $0.53-0.56$ ) as well as complete it on-time (OR 0.66; 95\% CI $0.64-0.69$ ) (Table 3). American Indians were also less likely to complete the series (OR 0.68; 95\% CI $0.61-0.77$ ) and do so on-time (OR $0.58 ; 95 \%$ CI $0.49-0.69)$ than Whites. Hispanics were less likely to complete the series (OR $0.75 ; 95 \%$ CI $0.72-0.79$ ) and do so on-time than non-Hispanics (OR $0.84 ; 95 \%$ CI $0.79-0.90)$. Young women were less likely to complete the series than the adolescents (OR $0.54 ; 95 \%$ CI $0.52-0.56$ ), but were more likely to finish the series on-time (OR 1.08; 95\% CI 1.03 - 1.14) if completed. Those who lived outside a metropolitan statistical area were also more likely both to complete the series and do so on-time. Those whose clinic type was a family medicine practice or local health department were less likely to complete the series than those whose clinic was a pediatric practice. Patients who went to family medicine practices, however, were more likely to complete the series on-time than patients of pediatric clinics. The females who saw providers in K-12 schools, however, were much more likely to both complete the series and do so on-time than those who went to pediatric clinics (OR 2.40; 95\% CI 1.82 3.17 and OR 1.77; $95 \%$ CI $1.30-2.39$, respectively). Public funding for vaccines was associated with lower completion rates (OR: 0.69, $0.68-0.71)$ and on-time dosing rates (OR: 0.80, $0.77-$ 0.83) when compared with private funding.

The results for the logistic regression model using a complete-case analysis are similar to the model with dummy variables for unknown data, except that local health departments and Hispanic ethnicity became statistically insignificant for on-time dosing. For series completion, age (9-12 years) also became insignificant. 


\section{Discussion}

Using a large statewide database, we found that after three years of availability on the market, completion of the HPV vaccine series among those who initiate it is low (overall 55\%), and on-time dosing of the vaccine is even lower (overall 28\%). When examining completion rates stratified by the year the patient initiated the vaccine, the percentage of those completing the series increased steadily over time (32\% after one year to $84 \%$ after three years). Most of the girls and young women completing the vaccination series, however, did so within one year $(82 \%)$. The percentage of those completing the series on-time, however, has decreased from $43 \%$ of those who initiated the series in 2006 to $25 \%$ for those who initiated in 2009 . This likely means a sizeable majority of those who started the series will complete it, but not on-time.

African Americans and Hispanics were less likely to complete the series and receive all doses on-time compared to Whites and non-Hispanics. Furthermore, private funding for the vaccine was associated with higher odds of completion and on-time dosing compared to public funding. These results are in agreement with previous studies about HPV vaccination completion, which also found that African Americans and those on public health insurance were less likely than those of other races or those with private health insurance to complete the series. ${ }^{17-19,30}$ Studies examining factors associated with reduced vaccine series completion have shown mixed results ${ }^{19,30} \cdot{ }^{20,26}$ Differences may be secondary to the vast differences in study population demographics. Nevertheless, the results from our study indicate that the rates of completion of the series as well as on-time dosing of the three doses differ across racial and socioeconomic groups, a finding that is consistent with the few existing studies investigating correlates for completion (and not initiation).More work is needed to develop and test interventions or programs that aim to eliminate disparities in vaccination rates. 
We found the factors associated with series completion and on-time dosing to be similar but not identical. For example, our data suggest that young women (18-26 year olds) are much less likely to complete the series than the adolescents(13-17 year olds), but of those who do, are more likely to complete it on-time. Our results are in agreement with other studies that have shown that college-age women are much less likely to initiate the vaccine than younger girls. ${ }^{20-21,26}$ This finding might be due to the fact that young adult women are not covered under the Vaccine for Children Program, or they might have lost insurance previously provided by their parent's private coverage. Nevertheless, the observation that of those who do complete the series, those in the adult age range are more likely to complete it on-time may be due to their ability to have a more flexible schedule than younger girls. Furthermore, compared to younger women, older women may exhibit more health care seeking activities and hence have more opportunities for HPV vaccination. One such example is the pap test, which has been shown in one study to be a predictor of HPV vaccination amongst daughters of mothers with a history of regular pap smears. ${ }^{22}$ Our result, however, is in contrast to one other study by Chao, et al., which found that those aged 18-26 years old had higher vaccination completion rates than younger girls aged 9-17 year old $(47.1 \%$ versus $41.9 \%) .{ }^{17}$ This latter study was limited by a fairly small sample in the older age group and only looked at women within a managed care organization which eliminates observed differences in insurance coverage between older women and younger girls as a potential barrier to vaccination completion.

With regards to clinic type, patients of who saw providers at pediatric clinics were more likely than those of at family medicine practices and local health departments to complete the series. This finding is in contrast to that in a study by Chao, et al., which stated that patients of pediatricians had lower completion rates than patients of family medicine or internal medicine 
physicians. ${ }^{17}$ The study populations between our study and the study by Chao, et al., are very different, but the reason for the contrasting results between studies is unclear. Patients immunized by providers at K-12 schools were much more likely to complete the series and complete the series on-time than those seen at pediatric clinics, but the results need to be tempered by the fact that this subgroup had a relatively small sample size $(n=244)$. Larger samples need to be gathered before these results can be assuredly generalized to the external source population, but these results are in agreement with other studies that have shown that school-based vaccination programs are effective at series completion. ${ }^{32}$ Studies have shown that physician recommendations are very important in determining vaccine uptake, ${ }^{29,33}$ and thus any differences in clinic type vaccination rates may be due to the differences in acceptability of the vaccine amongst providers. $^{34-35}$ If that is the case, interventions targeted at improving provider acceptance of the vaccine as well as improving provider recommendation of the vaccine to the target population (ideally females 11-12 years of age) would increase vaccination rates. ${ }^{36}$

Living in a rural area (non-Metropolitan Statistical Area) was statistically significantly associated with increased completion and on-time dosing rates, but the clinical importance of such a result is not compelling. This is in agreement with other studies which found that distance from a clinic was not associated with differences in completion rates. ${ }^{18}$ The differences among county vaccination rates are probably due to differences in area poverty and socioeconomic status rather than rurality, as shown by one study looking at HPV vaccination rates and geographic disparities. $^{37}$

\section{Strengths and Limitations}

One of the strengths of the study is the data source: the North Carolina Immunization Registry (NCIR), based on the Wisconsin Immunization registry, is a well-validated and robust 
Immunization Information System that satisfies the 12 minimum functional standards developed by the CDC. ${ }^{38}$ The most current numbers suggest that the NCIR has strong penetrance among the providers in the state; as of $2009,61 \%$ of private providers and $72 \%$ of public providers (including all local health departments) were using the registry to record immunization records (personal correspondence, 2010). It is also a large repository of data; 138,823 separate patients were used for analysis, which makes the results very robust. Furthermore, the patient sample is diverse, which allows for more generalizable results. Nevertheless, the registry is only robust if the data entry is complete. Inconsistencies in how each practice records its immunizations, systematic differences between practices inside the registry from those outside the registry, and the migration of people in and out of the system will make it more difficult to generalize the results from this study.

The biggest limitation to this study was the large proportion of entries with some missing data. Many entries were missing data about race, ethnicity, funding source, and county of residence. This limited the number of females available for analysis using the regression model, but the logistic model utilizing dummy variables for unknown values did not change the results drastically, which is reassuring to the validity of the results, even with missing data. Multiple imputation was considered as a method to evaluate the effect of missing data on the outcomes. However, the dataset had limited variables from which we could draw upon for imputation of all the missing data. Also, we were uncomfortable with the assumption that variables were missing at random, and were not willing to impute race (and other missing variables) based on the outcome, which we would then use to make conclusions about the associations between these exposures and the outcome. Thus we decided to compare the complete-case analysis and a model using all entries with dummy variables for unknown values. 


\section{Conclusions and Implications}

Among girls and young women who initiate the HPV vaccination series, overall completion rates are low, but given enough time (three years), most of those who begin the series will complete it. On-time dosing rates, however, are declining, and have been hovering at $25 \%$ for the past two years. The significance of delayed dosing with respect to vaccine immunogenicity and vaccine effectiveness are not well defined.

Additional studies are currently underway to assess how the late timing of the intervals between the doses affects the humoral immune response. ${ }^{13-16}$ The factors associated with completion and on-time dosing are similar. African-American race, Hispanic ethnicity, and having public insurance are associated with reduced series completion and on-time dosing. Efforts are needed to eliminate disparities in HPV vaccine delivery. Finally, if future research shows that delayed dosing leads to reduced vaccine immunogenicity, then new vaccines with reduced dosing requirements or strategies designed to improve on-time vaccine delivery will be needed. 


\section{References:}

1. CDC. Quadrivalent Human Papillomavirus Vaccine: Recommendations of the Advisory Committee on Immunization Practices (ACIP). MMWR. 2007;56(RR-2):1-32.

2. Garland SM, Hernandez-Avila M, Wheeler CM, et al. Quadrivalent vaccine against human papillomavirus to prevent anogenital diseases. $N$ Engl J Med. May 10 2007;356(19):1928-1943.

3. Dailard C. The Public Health Promise and Potential Pitfalls Of the World's First Cervical Cancer Vaccine: Guttmacher Institute;2006.

4. Prevention of human papillomavirus infection: provisional recommendations for immunization of girls and women with quadrivalent human papillomavirus vaccine. Pediatrics. Sep 2007;120(3):666-668.

5. FDA licensure of bivalent human papillomavirus vaccine (HPV2, Cervarix) for use in females and updated HPV vaccination recommendations from the Advisory Committee on Immunization Practices (ACIP). MMWR Morb Mortal Wkly Rep. May 28 2010;59(20):626-629.

6. FDA licensure of quadrivalent human papillomavirus vaccine (HPV4, Gardasil) for use in males and guidance from the Advisory Committee on Immunization Practices (ACIP). MMWR Morb Mortal Wkly Rep. May 28 2010;59(20):630-632.

7. Charo RA. Politics, parents, and prophylaxis--mandating HPV vaccination in the United States. N Engl J Med. May 10 2007;356(19):1905-1908.

8. CDC. National, State, and Local Area Vaccination Coverage Among Adolescents Aged 13--17 Years --- United States, 2008. MMWR. 2009;58(36):997-1001.

9. Quadrivalent vaccine against human papillomavirus to prevent high-grade cervical lesions. N Engl J Med. May 10 2007;356(19):1915-1927.

10. Luman ET, Barker LE, Shaw KM, McCauley MM, Buehler JW, Pickering LK. Timeliness of childhood vaccinations in the United States: days undervaccinated and number of vaccines delayed. JAMA. Mar 9 2005;293(10):1204-1211.

11. Heininger U, Loos K, Lorenz I, Rascher W. Compliance with recommended immunizations in adolescents. Eur J Pediatr. Oct 2006;165(10):671-676.

12. Lopreiato JO, Ottolini MC. Assessment of immunization compliance among children in the Department of Defense health care system. Pediatrics. Mar 1996;97(3):308-311.

13. Gardasil - Package Insert. 2009; http://www.fda.gov/downloads/BiologicsBloodVaccines/Vaccines/ApprovedProducts/U CM111263.pdf.

14. Alternate Dosing Schedules Study for HPV Vaccine (ADS). Bethesda (MD): National Library of Medicine (US); cited 2010 March 10.

15. Randomized Trial of Alternative Quadrivalent Human Papilloma Virus (HPV) Vaccination Schedules in a University Setting. Bethesda (MD): National Library of Medicine (US); cited 2010 March 10.

16. Immunogenicity of Off-Schedule Dosing of HPV Vaccine. Bethesda (MD): National Library of Medicine (US); cited 2010 March 10.

17. Chao C, Velicer C, Slezak JM, Jacobsen SJ. Correlates for completion of 3-dose regimen of HPV vaccine in female members of a managed care organization. Mayo Clin Proc. Oct 2009;84(10):864-870. 
18. Neubrand TP, Breitkopf CR, Rupp R, Breitkopf D, Rosenthal SL. Factors associated with completion of the human papillomavirus vaccine series. Clin Pediatr (Phila). Nov 2009;48(9):966-969.

19. Dempsey A, Cohn L, Dalton V, Ruffin M. Patient and clinic factors associated with adolescent human papillomavirus vaccine utilization within a university-based health system. Vaccine. Jan 22 2010;28(4):989-995.

20. Chao C, Velicer C, Slezak JM, Jacobsen SJ. Correlates for human papillomavirus vaccination of adolescent girls and young women in a managed care organization. Am J Epidemiol. Feb 1 2010;171(3):357-367.

21. Conroy K, Rosenthal SL, Zimet GD, et al. Human papillomavirus vaccine uptake, predictors of vaccination, and self-reported barriers to vaccination. J Womens Health (Larchmt). Oct 2009;18(10):1679-1686.

22. Chao C, Slezak JM, Coleman KJ, Jacobsen SJ. Papanicolaou screening behavior in mothers and human papillomavirus vaccine uptake in adolescent girls. Am J Public Health. Jun 2009;99(6):1137-1142.

23. Dempsey AF, Singer D, Clark SJ, Davis MM. Parents' views on 3 shot-related visits: implications for use of adolescent vaccines like human papillomavirus vaccine. Acad Pediatr. Sep-Oct 2009;9(5):348-352.

24. Jain N, Euler GL, Shefer A, Lu P, Yankey D, Markowitz L. Human papillomavirus (HPV) awareness and vaccination initiation among women in the United States, National Immunization Survey-Adult 2007. Prev Med. May 2009;48(5):426-431.

25. Kahn JA, Rosenthal SL, Jin Y, Huang B, Namakydoust A, Zimet GD. Rates of human papillomavirus vaccination, attitudes about vaccination, and human papillomavirus prevalence in young women. Obstet Gynecol. May 2008;111(5):1103-1110.

26. Licht AS, Murphy JM, Hyland AJ, Fix BV, Hawk LW, Mahoney MC. Is use of the HPV vaccine among female college students related to HPV knowledge and risk perception? Sex Transm Infect. Oct 192009.

27. Patel M, Zandieh S, Chang J. Are Our Adolescent Females Becoming "One Less"? HPV Vaccination Rates and Barriers to Vaccination. Journal of Adolescent Health. 2009;44(2, Supplement 1):S28-S29.

28. Reiter PL, Brewer NT, Gottlieb SL, McRee AL, Smith JS. How much will it hurt? HPV vaccine side effects and influence on completion of the three-dose regimen. Vaccine. Nov 16 2009;27(49):6840-6844.

29. Rosenthal SL, Weiss TW, Zimet GD, Ma L, Good MB, Vichnin MD. Predictors of HPV vaccine uptake among women aged 19-26: Importance of a physician's recommendation. Vaccine. Jan 52010.

30. National, state, and local area vaccination coverage among adolescents aged 13-17 years-United States, 2008. MMWR Morb Mortal Wkly Rep. Sep 18 2009;58(36):997-1001.

31. NC State Data Center. Metropolitan Statistical Areas, 2003. 2003; http://www.osbm.state.nc.us/ncosbm/facts_and_figures/census//maps/cbsa_list.html. Accessed March 9, 2010.

32. Brabin L, Roberts SA, Stretch R, et al. Uptake of first two doses of human papillomavirus vaccine by adolescent schoolgirls in Manchester: prospective cohort study. BMJ. May 10 2008;336(7652):1056-1058. 
33. Gottlieb SL, Brewer NT, Sternberg MR, et al. Human papillomavirus vaccine initiation in an area with elevated rates of cervical cancer. J Adolesc Health. Nov 2009;45(5):430437.

34. Dempsey AF, Davis MM. Overcoming barriers to adherence to HPV vaccination recommendations. Am J Manag Care. Dec 2006;12(17 Suppl):S484-491.

35. Riedesel JM, Rosenthal SL, Zimet GD, et al. Attitudes about human papillomavirus vaccine among family physicians. J Pediatr Adolesc Gynecol. Dec 2005;18(6):391-398.

36. Cardarelli R, Cardarelli KM. Recommendations for primary care physicians to improve HPV vaccination rates during clinical encounters. Osteopath Med Prim Care. 2008;2:10.

37. Pruitt SL, Schootman M. Geographic disparity, area poverty, and human papillomavirus vaccination. Am J Prev Med. May 2010;38(5):525-533.

38. Heitz R. Wisconsin's immunization registry. WMJ. Jul 2005;104(5):83-86. 
Table 1. Characteristics of Girls and Young Women in Study Sample $(n=138,823)$

\begin{tabular}{|c|c|}
\hline & Percentage \\
\hline \multicolumn{2}{|c|}{ Race $(n=113,309)$} \\
\hline American Indian / Alaskan Native & $1.2 \%$ \\
\hline Asian & $1.3 \%$ \\
\hline Black & $33.1 \%$ \\
\hline Native Hawaiian / Pacific Islander & $0.1 \%$ \\
\hline Other & $1.4 \%$ \\
\hline White & $62.9 \%$ \\
\hline \multicolumn{2}{|c|}{ Ethnicity $(\mathrm{n}=96,110)$} \\
\hline Hispanic & $9.0 \%$ \\
\hline Non-Hispanic & $91.0 \%$ \\
\hline \multicolumn{2}{|c|}{ Age at First Dose $(n=138,823)$} \\
\hline 9-12 years old & $28.2 \%$ \\
\hline 13-17 years old & $57.1 \%$ \\
\hline $18-26$ years old & $14.7 \%$ \\
\hline \multicolumn{2}{|c|}{ County $(n=136,497)$} \\
\hline Metropolitan Statistical Area & $70.5 \%$ \\
\hline Non-MSA & $29.5 \%$ \\
\hline \multicolumn{2}{|c|}{ Clinic Type $(\mathrm{n}=138,823)$} \\
\hline Family Provider & $23.5 \%$ \\
\hline Local Health Department & $18.8 \%$ \\
\hline Pediatric Provider & $56.5 \%$ \\
\hline Hospital & $0.3 \%$ \\
\hline Internal Medicine Provider & $0.2 \%$ \\
\hline Juvenile Corrections & $0.1 \%$ \\
\hline School K-12 & $0.2 \%$ \\
\hline University/College & $0.3 \%$ \\
\hline Other & $0.1 \%$ \\
\hline \multicolumn{2}{|c|}{ Funding Type $(\mathrm{n}=110,783)$} \\
\hline Private & $51.2 \%$ \\
\hline Public & $48.8 \%$ \\
\hline
\end{tabular}


Table 2. Associations with HPV Vaccination Series Completion and On-Time Completion

\begin{tabular}{|c|c|c|c|c|}
\hline Characteristic & $\begin{array}{c}\text { Total } \\
\text { Number }\end{array}$ & $\begin{array}{c}\text { \% Completed } \\
\text { Series }\end{array}$ & $\begin{array}{c}\text { Total } \\
\text { Number }\end{array}$ & $\begin{array}{c}\% \text { All } 3 \\
\text { doses on } \\
\text { time }\end{array}$ \\
\hline \multicolumn{5}{|l|}{ Race $(n=113,309)$} \\
\hline American Indian / Alaskan Native & 1,325 & $47.2 \%$ & 625 & $41.0 \%$ \\
\hline Asian & 1,486 & $56.0 \%$ & 832 & $50.6 \%$ \\
\hline Black & 37,490 & $43.4 \%$ & 16,275 & $43.1 \%$ \\
\hline Native Hawaiian / Pacific Islander & 136 & $50.7 \%$ & 69 & $53.6 \%$ \\
\hline Other & 1,616 & $56.0 \%$ & 905 & $47.5 \%$ \\
\hline White & 71,256 & $59.0 \%$ & 42,037 & $54.5 \%$ \\
\hline \multicolumn{5}{|l|}{ Ethnicity $(\mathrm{n}=96,110)$} \\
\hline Hispanic & 8,633 & $46.3 \%$ & 3,995 & $47.0 \%$ \\
\hline Non-Hispanic & 87,477 & $53.5 \%$ & 46,801 & $50.9 \%$ \\
\hline \multicolumn{5}{|l|}{ County $(n=136,497)$} \\
\hline Metropolitan Statistical Area & 96,188 & $55.3 \%$ & 53,233 & $49.8 \%$ \\
\hline Non-MSA & 40,309 & $54.2 \%$ & 21,838 & $54.2 \%$ \\
\hline \multicolumn{5}{|l|}{ Clinic Type $(n=138,823)$} \\
\hline Family Provider & 32,652 & $52.9 \%$ & 17,258 & $56.2 \%$ \\
\hline Local Health Department & 26,154 & $39.4 \%$ & 10,314 & $49.6 \%$ \\
\hline Pediatric Provider & 78,425 & $61.3 \%$ & 48,081 & $49.8 \%$ \\
\hline Hospital & 435 & $41.2 \%$ & 179 & $39.1 \%$ \\
\hline Internal Medicine Provider & 234 & $53.9 \%$ & 126 & $37.3 \%$ \\
\hline Juvenile Corrections & 92 & $54.4 \%$ & 50 & $56.0 \%$ \\
\hline School K-12 & 244 & $70.5 \%$ & 172 & $54.7 \%$ \\
\hline University/College & 434 & $51.4 \%$ & 223 & $50.2 \%$ \\
\hline Other & 153 & $57.5 \%$ & 88 & $37.5 \%$ \\
\hline \multicolumn{5}{|l|}{ Funding Type $(\mathrm{n}=110,783)$} \\
\hline Private & 56,711 & $61.2 \%$ & 34,686 & $53.6 \%$ \\
\hline Public & 54,072 & $45.6 \%$ & 24,652 & $47.3 \%$ \\
\hline \multicolumn{5}{|l|}{ Age at First Dose $(\mathrm{n}=\mathbf{1 3 8 , 8 2 3})$} \\
\hline $9-12$ years old & 39,166 & $57.5 \%$ & 22,515 & $50.0 \%$ \\
\hline 13-17 years old & 79,325 & $57.4 \%$ & 45,492 & $51.0 \%$ \\
\hline $18-26$ years old & 20,332 & $41.7 \%$ & 8,484 & $55.1 \%$ \\
\hline
\end{tabular}

* Note: All Pearson's Chi-Squared values were $<0.001$. 
Table 3. Adjusted Associations with HPV Vaccination Series Completion and On-Time Completion

\begin{tabular}{|c|c|c|c|c|}
\hline \multicolumn{5}{|c|}{ Adjusted for Race, Ethnicity, County Status, Clinic Type, Funding Source, and Age of first dose } \\
\hline & $\begin{array}{l}\text { OR for Series } \\
\text { Completion } \\
(\mathrm{n}=138,823)\end{array}$ & $\begin{array}{c}95 \% \\
\text { Confidence } \\
\text { Interval }\end{array}$ & $\begin{array}{c}\text { OR for } \\
\text { On-Time } \\
\text { Dosing } \\
(\mathrm{n}=76,491)\end{array}$ & $\begin{array}{c}95 \% \\
\text { Confidence } \\
\text { Interval }\end{array}$ \\
\hline \multicolumn{5}{|l|}{ Race (White as Referent) } \\
\hline American Indian or Alaska Native & 0.68 & $0.61-0.77$ & 0.58 & $0.49-0.69$ \\
\hline Asian & 1.04 & $0.94-1.16$ & 0.99 & $0.85-1.14$ \\
\hline Black or African-American & 0.55 & $0.53-0.56$ & 0.66 & $0.64-0.69$ \\
\hline Native Hawaiian or Pacific Islander & 0.78 & $0.56-1.11$ & 1.10 & $0.68-1.78$ \\
\hline Other & 1.12 & $1.01-1.25$ & 0.88 & $0.77-1.01$ \\
\hline Unknown & 0.94 & $0.90-0.97$ & 0.90 & $0.86-0.94$ \\
\hline \multicolumn{5}{|l|}{$\begin{array}{l}\text { Ethnicity (non-Hispanic as } \\
\text { Referent) }\end{array}$} \\
\hline Hispanic & 0.75 & $0.72-0.79$ & 0.84 & $0.79-0.90$ \\
\hline Unknown & 0.97 & $0.94-0.99$ & 1.01 & $0.97-1.05$ \\
\hline \multicolumn{5}{|l|}{ County Status (MSA as Referent) } \\
\hline Non-MSA & 1.04 & $1.01-1.07$ & 1.23 & $1.19-1.27$ \\
\hline Unknown & 0.97 & $0.89-1.06$ & 1.07 & $0.96-1.19$ \\
\hline \multicolumn{5}{|l|}{$\begin{array}{c}\text { Clinic Type (Pediatrician as } \\
\text { Referent) }\end{array}$} \\
\hline Family Provider & 0.78 & $0.76-0.80$ & 1.34 & $1.29-1.39$ \\
\hline Local Health Department & 0.48 & $0.47-0.50$ & 1.08 & $1.03-1.13$ \\
\hline Hospital & 0.49 & $0.40-0.59$ & 0.82 & $0.61-1.12$ \\
\hline Internal Medicine & 0.75 & $0.57-0.98$ & 0.69 & $0.47-1.00$ \\
\hline Juvenile Corrections & 0.86 & $0.57-1.31$ & 1.71 & $0.97-2.99$ \\
\hline$K-12$ School & 2.40 & $1.82-3.17$ & 1.77 & $1.30-2.39$ \\
\hline University/College & 0.72 & $0.59-0.87$ & 0.93 & $0.71-1.21$ \\
\hline Other & 1.24 & $0.89-1.75$ & 0.82 & $0.52-1.30$ \\
\hline \multicolumn{5}{|l|}{$\begin{array}{c}\text { Funding Source (Private as the } \\
\text { Referent) }\end{array}$} \\
\hline Public Funding & 0.69 & $0.68-0.71$ & 0.80 & $0.77-0.83$ \\
\hline Unknown & 1.23 & $1.20-1.27$ & 0.90 & $0.87-0.94$ \\
\hline \multicolumn{5}{|l|}{ Age (13-17 as Referent) } \\
\hline Age 9-12 & 0.97 & $0.95-1.00$ & 0.99 & $0.95-1.02$ \\
\hline Age 18-26 & 0.54 & $0.52-0.56$ & 1.08 & $1.03-1.14$ \\
\hline
\end{tabular}




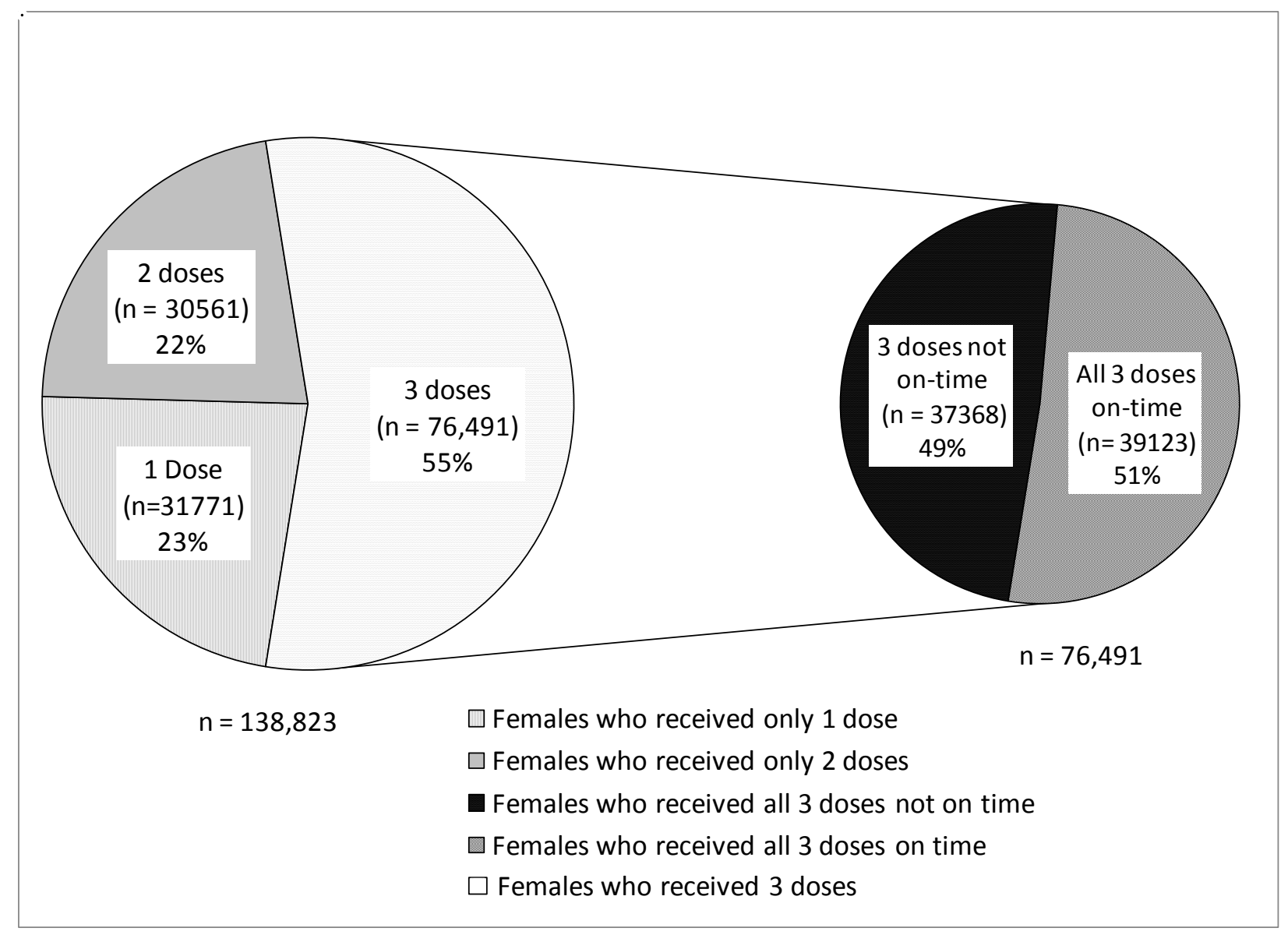

Figure 1. The pie graph on the left indicates the proportions of females aged 9-26 years of age receiving differing numbers of doses of HPV vaccine. The pie chart on the right displays the proportions of females who completed the series that received all three doses on-time or not ontime. 


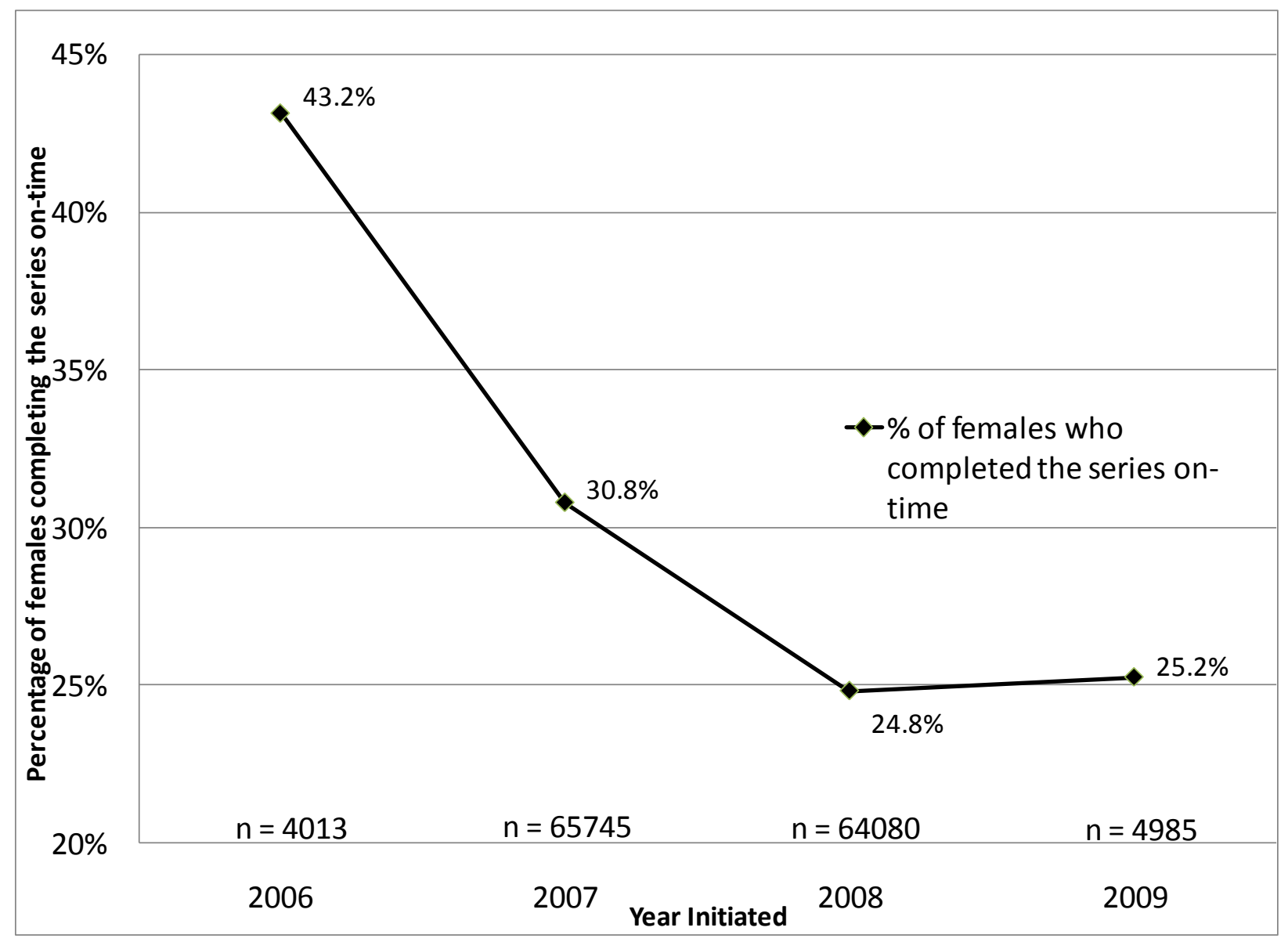

Figure 2. The percentage of females who completed the HPV vaccine series on-time stratified by the year the HPV vaccine series was initiated. The number of females who initiated the series in each year is shown above the year indicated. 